\title{
The Effects of Interventions Targeting Increased Organic Seed Use-The Cases of Perennial Ryegrass in England and Durum Wheat in Italy
}

\author{
Eva Winter ${ }^{1,2}{ }^{*}$, Christian Grovermann ${ }^{1}$, Stefano Orsini ${ }^{3}$, Francesco Solfanelli ${ }^{4}$ and Joachim Aurbacher ${ }^{2}$ \\ 1 Department of Socioeconomics, Research Institute of Organic Agriculture (FiBL), 5070 Frick, Switzerland; \\ christian.grovermann@fibl.org \\ 2 Institute of Farm and Agribusiness Management, Justus-Liebig University of Giessen, \\ 35390 Giessen, Germany; joachim.aurbacher@agrar.uni-giessen.de \\ 3 The Organic Research Centre, Trent Lodge, Stroud Rd, Cirencester GL7 6JN, UK; steorsini@outlook.com \\ 4 Department of Agricultural, Food and Environmental Sciences (D3A), Università Politecnica delle Marche, \\ 60131 Ancona, Italy; f.solfanelli@agrecon.univpm.it \\ * Correspondence: eva.winter@fibl.org
}

check for updates

Citation: Winter, E.; Grovermann, C.; Orsini, S.; Solfanelli, F.; Aurbacher, J.

The Effects of Interventions Targeting Increased Organic Seed Use-

The Cases of Perennial Ryegrass in England and Durum Wheat in Italy. Sustainability 2021, 13, 13326.

https://doi.org/10.3390/su132313326

Academic Editor: Alessandra

Durazzo

Received: 19 October 2021

Accepted: 22 November 2021

Published: 1 December 2021

Publisher's Note: MDPI stays neutral with regard to jurisdictional claims in published maps and institutional affiliations.

Copyright: (c) 2021 by the authors. Licensee MDPI, Basel, Switzerland. This article is an open access article distributed under the terms and conditions of the Creative Commons Attribution (CC BY) license (https:// creativecommons.org/licenses/by/ $4.0 /)$.

\begin{abstract}
To meet policy goals targeting increasing the share of organic agriculture, an organic seed needs to be provided. Currently, this is far from being the case. This study investigates two cases of important crop country combinations in organic agriculture, namely perennial ryegrass in South-West England and durum wheat in Italy. A novel multi-agent value chain approach was developed to assess public and private-sector interventions aiming at increasing organic seed use. Phasing out of derogations for non-organic seed comes with $2-7 \%$ gross margin losses at the farm level. Seed producers and breeders profit by $9-24 \%$. Mitigating measures can be subsidies of $28 € /$ ha or price premiums of $12 € /$ ton at the farm gate for durum wheat, in the case of durum wheat in Italy, and subsidies of $13 € /$ ha or price premiums of $70 € /$ ton for lamb meat, in the case of perennial ryegrass in England. Further mitigating measures are the promotion of farm-saved durum wheat seed and investments in breeding for better nitrogen efficiency in organic perennial ryegrass seed production.
\end{abstract}

Keywords: organic seed; value chain analysis; agent-based modelling; policies; farm to fork strategy

\section{Introduction}

The governmental goal to increase the organic land area in Europe has become a priority in the European Union (EU) policy agenda to facilitate a sustainable food system transformation. An example is the Farm-to-Fork strategy of the EU [1], which sets the ambitious goal to increase the organic land area in Europe by $25 \%$ by 2030 . An essential aspect in the organic value chain that needs to be tackled simultaneously is the increase in organic seed use by organic farmers: a key principle of organic farming is that inputs need to be organic, including seeds. This is an unresolved challenge of the organic sector since organically multiplied seed use remains the norm for a small share of organic farmers. For example, the use of non-chemically treated (NCT) non-organic seeds for important cereals like barley and maize across the EU still lies between 25 and 44\%; for legumes like soybean and lucerne, the percentage ranges between 34 and 47\% [2]. Addressing the unresolved issues relating to the organic seed sector has become as relevant as the new Organic Regulation (EC/848/2018), which will come into force from 2022 and envisages that all derogations for non-organic seeds will be phased out by 2036 [3].

Insufficient organic seed supply has been a challenge since the implementation of the EU organic regulation in 1992. To mitigate this, a derogation system (This system comprises three different categories in which crop species and sub-species can be classified according to their availability in organic quality: Category I = no derogations are possible; Category II = single derogations are possible if desired cultivars are not available in organically 
multiplied quality; Category III = a general derogation applies, and the application for the use of non-organic seed is not necessary.) was put into action, allowing farmers to apply for the use of non-organic seeds. Although this permits the EU organic regulation to be functional, it hampers at the same time the development of a market for organic seeds [4]. In 2004, an attempt at phasing out the derogation system was made but not followed through, as the risk of a severe seed shortage was apparent. Although it seems that the organic sector generally acknowledges the need for coordinated interventions [5], it seems unclear which interventions should be preferred.

In this paper, we shed light on the situation regarding organic seeds by focusing on two key crops in two selected countries and the effects of seed system interventions targeting increased organic seed use and production. After a descriptive analysis of the status quo for the two case studies, we simulate and analyse potential policy and market interventions as to their capacity to increase organic seed use and production. We focus on specific crops and countries because the implementation of the EU organic regulation concerning the derogation system regarding the categorisation of species and sub-species differs between countries [4]. The chosen crops and countries are organic durum wheat in Italy and perennial (per.) ryegrass intercropped with white clover in England. These case combinations were selected for their importance in the respective organic crop sectors, i.e., cereals and forage. Although the United Kingdom (UK) is no longer part of the EU and the strategy regarding derogations has not yet been decided upon, the results of this study can still serve as guidance to other countries with a large forage sector and similar climatic conditions. A third case, which is beyond the scope of this paper, involves carrots in Germany; this investigation examines the vegetable sector (for further information, see [6]).

Currently, durum wheat is not in Category 1 in any country and is in Category 3 in Italy. In recent years, there has been a strong increase in derogations for untreated conventional seeds, which is also related to the increase in the area used to grow organic durum wheat. However, throughout the EU, the trend regarding derogations has been increasing disproportionally $(+55 \%)$ compared to the organic land area (+39\%) [7]. Next to the control and command measure of phasing out derogations, some policy schemes are in place which voluntarily support organic seed use and production. The Estonian government supports the use of certified organic seeds for cereals with a $20 \%$ premium, with which the EU Common Agricultural Policy (CAP) area payments are topped up for the area where organic seeds are used. In the Czech Republic and Slovenia, similar measures have been put in place. In Lithuania, organic seed production is supported with additional payments under the Rural Development Program (RDP) scheme. In Latvia, training on seed production is offered to organic farmers [8]. For cereal seed production, an additional endorsement of $€ 273$ per hectare is paid [7]. Issues arising when targeting increased organic durum wheat seed production and use are the lack of suitable cultivars, pests and diseases in organic seed production (e.g., common bunt), the derogation system itself, and a lack of farmers' training to produce farm-saved seeds [7]. One prospect to make organic seed use more attractive could be the promotion of cultivars specifically bred and thus particularly suitable for organic agriculture. An example of such a cultivar group is Organic Heterogeneous Material (OHM). Some studies show that OHM can have high yield stability and low external input needs, making them particularly suited for low input systems $[9,10]$.

As for the forage sector, forage crops are normally sown as mixtures, but there is not a common rule across Europe: some countries consider the organic content in the seed mixture as a whole, whilst others consider the organic content of each seed component individually. In most countries such as the UK, Switzerland, France, Germany, and Belgium, it is currently sufficient that an established share of seeds in the forage mixture is organic (usually $70 \%$ ) for the whole mixture to be considered organic. Perennial ryegrass is in Category 1 only in Belgium, whereas no country has placed white clover in Category 1. Perennial ryegrass is widely used in forage mixtures across Europe. It is often mixed with 
clover species. Data on derogations are provided as pooled data with derogation data for Italian ryegrass. The aggregate data indicates the highest increase in derogations (ca. 90\%) for the two crops from 2014 to 2016 within the European forage sector [7]. Production of organic forage seed is very limited in the United Kingdom, and most organic forage seed is imported from Denmark and the Netherlands [7]. White clover in forage mixtures is widely used across Europe too. Data on derogations, aggregated with red clover, indicate a substantial increase of $72 \%$ from 2014 to 2016 [7]. Mentioned challenges that hamper the increase in organic seed production and use are lower seed yields, less nitrogen efficiency, and high prices for organic perennial ryegrass seed, compared to NCT. Additionally, political insecurity concerning a potential phasing out of derogations is an issue. Lastly, crops with a small share in mixtures are judged to be economically unviable to be produced in organic quality [7]. The above-mentioned measures and bottlenecks serve as examples for interventions towards increased organic seed use and production.

The evidence laid out above shows that challenges and, at the same time, promising interventions to boost organic seed production and use are found at different levels of the value chain, namely breeding, seed multiplication, farming, food industry, and governmental level. Thus, a value chain perspective and analysis approach are needed to test these interventions. Furthermore, a quantitative ex-ante approach can deliver a sound economic assessment of different seed and breeding value chain interventions. Results based on simulation models far outweigh the accuracy of extrapolation from existing data [11]. Lastly, the decision-making of actors in the seed and breeding value chain, e.g., which seed to use or produce, seems vital to analyse which intervention would trigger such an uptake. The present study aims to close the knowledge gap on such methods, which are lacking in the current science of analysis of value chains [12,13].

We, therefore, developed a systematic ex-ante value chain approach based on simulation modelling and economic decision-making to assess the effects of interventions aiming to increase organic seed use and production. Moreover, as individual actors with competing interests make the most relevant decisions in the seed and breeding value chain, we depict those actors in a simplified multi-agent system. To summarise, this study addresses a dual research gap: first, it presents a novel approach for quantitative ex-ante value chain analysis; second, this approach is applied to test interventions aiming at increased organic seed use and production, a topic where little information is currently available, and which is of growing importance in the light of changing policies. This study is, to the best of our knowledge, the first to model these issues in a systematic way to provide actors with advice on the consequences of interventions in the organic sector.

The following section explains the model development in further detail, and data collected for the agents and interventions are considered. The modelling results are then presented. A discussion of the results and their implications on the organic seed sector closes the paper.

\section{Materials and Methods}

\subsection{Conceptual Framework of Modelling Approach}

Europe's organic seed value chain usually comprises five to seven stages, i.e., breeding, seed multiplication, seed trading, farming, processing, wholesale, and consumption, mainly depending on the crop of interest. For the simulation model, we focus on three value chain stages: breeding, multiplication, and farming, as they are likely to be the stages where the most important decisions take place. As a result, the following decisions taken at these three stages are modelled endogenously:

- Farming stage: crops grown in the crop rotation and type of seed used, i.e., NCT/organic seed, and from organic cultivar in some cases.

- Multiplication stage: type of seed and amount produced, i.e., NCT/organic seed, and from organic cultivar in some cases.

- Breeding stage: the amount of basic seeds for conventional, NCT, or organic seeds produced and marketed. 
Policy and food industry measures such as an introduction of a subsidy, or the decision of the food industry to pay a higher product price, have been included as exogenous factors in the model through scenarios. As regards the individual actors at each value chain stage, only the enterprise processes for either wheat or forages are modelled as opposed to the entire farm or company. This is most suitable for this model, as it is more resource-efficient and focuses on relevant business branches and activities.

\subsubsection{Decision Making of Actors}

Breeding, seed production, and farming are activities conducted by actors driven by economic considerations. Therefore, for each actor in the chain, a mathematical programming-based algorithm is implemented with the goal of optimising individual agents' gross margins. We consider that gross margin optimisation as the main decisionmaking driver is a valid assumption for the two cases at hand.

Mathematical Programming (MP) is used to simulate economically sound decisions within a process [14-16]. An example for a simple linear programming (LP) model (Equations (1)-(3)), as implemented for the value chain actors in this study, is demonstrated below:

$$
\begin{aligned}
& \text { Objective function (Gross Margin): } \max ! \mathrm{z}=\sum_{j} c_{j} x_{j} \\
& \text { Side constraint: } \sum_{j} a_{i, j} x_{j} \leq b_{i} \text { for all } i \\
& \text { Side constraint: } x_{j} \geq 0 \text { for all } j
\end{aligned}
$$

The objective value is ' $\mathrm{z}$ ', in this case, the gross margin that is maximised as the sum product of ' $c$ ' and ' $x$ '. The activities are represented by ' $x$ ' (such as growing different crops, buying inputs, etc.), and ' $c$ ' represents costs and revenues of activities over the index ' $j$ ', indicating the different possible activities. The objective function is subject to several side constraints, represented by inequalities of the products of activities and technical coefficients ' $a$ ' (e.g., the amount of labour needed for one hectare of growing potatoes) and ' $i$ ' given resource endowments $b$ (e.g., land or labour endowment).

Optimised objective values for the farming and seed-producing agents are the gross margins of organic carrot production and other crops in the crop rotation at the farm level and gross margins of carrot seed production at the seed multiplication level. At the breeding level, breeding agents optimise their breeding budget. The breeding budget is 10 to $30 \%$ of the seed sales revenue, depending on the typical actor. The yearly breeding budget enters the model as objective value at the breeding level because the typical breeding actors we identified do not consider the gross margin at the breeding level but require a constant breeding budget for research and development $[6,17,18]$.

Exemplary LP decision tables for agents of each value chain level can be found in the Appendix C, Tables A4-A6. An LP decision tableau is a standard method to represent sets of equations in an LP model [14]. In these tableaux, decision variables (' $x$ ') are shown in the first line, parameters representing technical coefficients ('a') can be found starting from column 4, line 5, farm gate prices and costs (' $c$ ') (e.g., last two lines), and right-hand side values ( ${ }^{\prime} b$ ') (last column) are indicated. Values in round brackets are adjusted inside the model. Bold values are agent specific. The tables give a comprehensive overview of the type of data used in the model, as well as on the variability of parameters.

\subsubsection{Interactions between Value Chain Stages and Actors}

The simulation model is time-dynamic so that we can observe developments over time. Eight modelling years are considered, which makes it possible to realistically model e.g., a stepwise phasing out of derogations. Interactions between actors of different value chain stages are based on sales of basic seeds. Compatibility of market sizes between the different value chain stages is ensured through scaling factors, which consider economies of scale. Furthermore, adaptive expectations [19] are implemented at the basic seed and seed production levels. The seed producers and breeders adapt their sales expectations and their basic seed and seed for farmers production based on former experiences. For this, 
growth expectation factors need to be calculated. These factors contain the value by how much seed production can be increased after one modelling year, based on how much was sold in that year. The growth expectation factors to allow seed producers to meet organic seed demand have been obtained by a calibration process. In the case of durum wheat, the seed producer can, at most, triple their production in one year, while the perennial ryegrass seed producer can double their production each year. This calibration was conducted using scenario 2 [Derog] (for more information, see Section 2.6, scenario development). This can be justified by seed expert judgment that organic seeds could match demand in a stepwise phasing out derogations scenario to leave enough time to identify suitable cultivars for organic seed production. This calibration was then used for the further scenarios, as the pace of the sector development can be assumed to be similar.

A sensitivity analysis was conducted by letting the model run ten times per scenario with different seed values and triangular distributions of crop yields (wheat case, no data available for per. ryegrass case) and prices (wheat and per. ryegrass case). The input data for these distributions can be found in the Appendix A, Tables A1-A3. A basic chart of the value chain model can be seen in Figure 1. This chart shows the different decision levels and feedback loops in one modelling year.

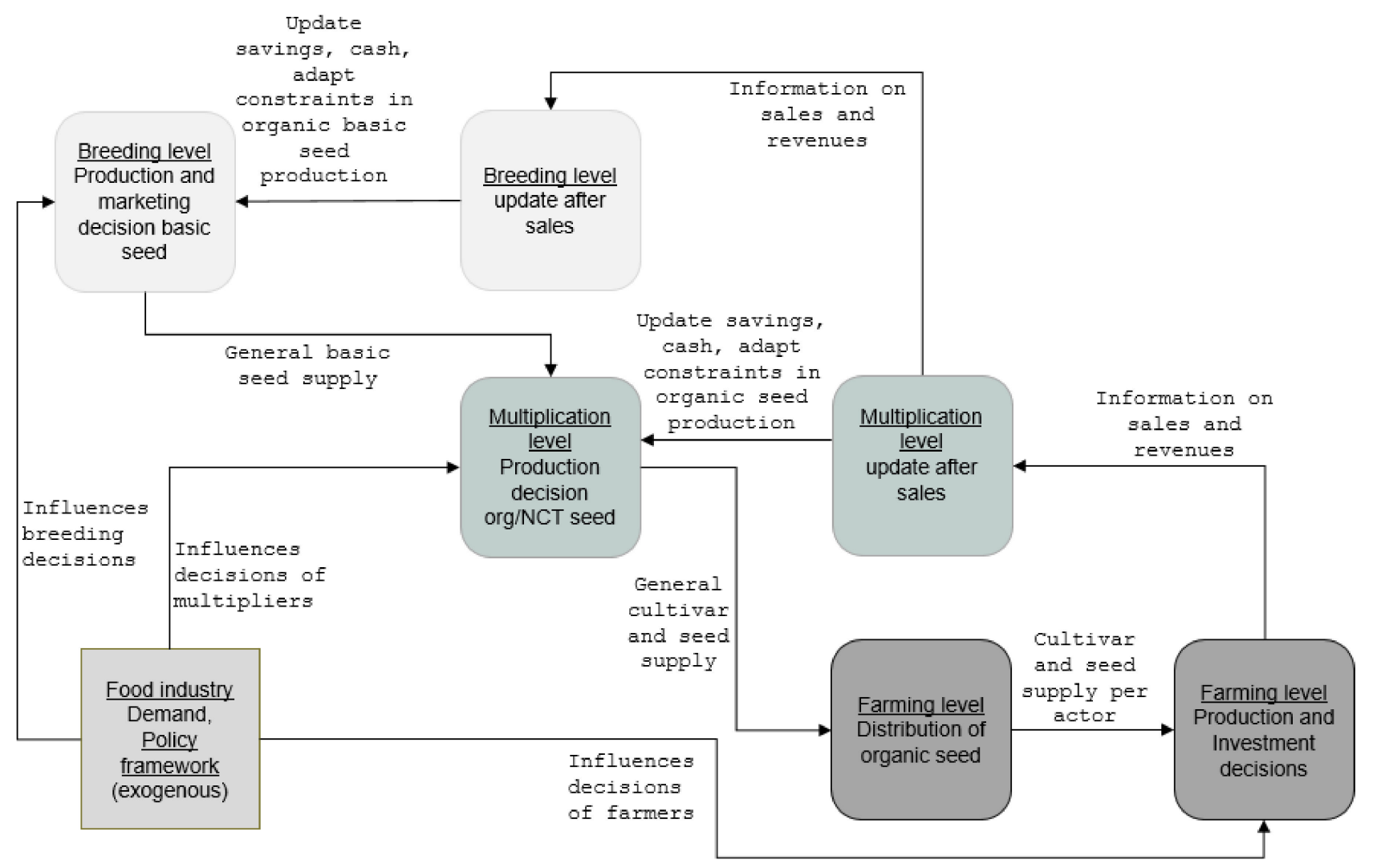

Figure 1. Conceptual chart of value chain simulation model.

\subsection{Typical Actors at Farm Level}

As data availability at the farm level for durum wheat in Italy and perennial ryegrass in England was limited, the published and established typical farm approach used by the Agri Benchmark network managed by the Thünen Institute of Farm economics was used to identify two typical production systems per case study crop [20,21]. "Typical" can be described also with "representative" or "most common". This means the described typical farm exists in reality and is not e.g., an artificial average of all farms [21]. In statistical terms, this is called the mode; the farm type that occurs the most in a distribution [22]. Moreover, we established that at least approximately $50 \%$ of the focus crop should be produced on these farm types in the selected regions. 
This approach has several advantages over other commonly used approaches. For example, the issue of particularities and lack of generalization of individual farm data with small or biased samples can be avoided [21]. Furthermore, it mitigates the issue of aggregation bias that occurs when using average data for model parameterisation [22]. Generally, the approach strives to combine sufficient data depth, consistency, and accuracy with reasonable time and resource input for data collection [21].

We endeavoured to test the effects of policy and market interventions on typical organic producers, covering at least the minimum of heterogeneity represented by two different production systems for each of the two case study crops. To identify typical production systems, the Standard Operational Procedure (SOP) as proposed in the typical farm approach was applied as far as the identification and data collection of farm types are concerned.

Firstly, regions and production systems were selected according to the following criteria. A relevant region is a region with a large share of the agricultural area dedicated to producing the focus crop or a high density of farms that produce the crop. More precisely, the three indicators were considered to identify the area:

- Total area (ha) of organic focus crop production in the region.

- Share of organic focus crop area of total agricultural farm area in the region.

- Share of organic focus crop area per 100 ha surface area in the region.

One medium-sized and one slightly larger enterprise, both with gross margin or sales revenue per focus crop farm enterprise close to the average of the farm population, were chosen. For all the above-mentioned points, we proceeded hierarchically, i.e., starting with the most specific (e.g., area of perennial ryegrass), and if this data was not available, we verified the area of ryegrass in general, and so on. Subsequently, the further steps of SOP data collection, data processing, and data cross-checking were conducted. The main criteria after the identification of the regions where most of the focus crops are produced were typical farm size, typical crop production system (crop rotation, input use), and typical marketing channels. A more detailed description of the chosen typical systems can be found in Section 2.5 .

\subsection{Defining Typical Companies and Initiatives at Seed Production and Breeding Levels}

In both cases, typical breeding and seed production entities were identified. The approach to depict typical processes was selected considering data availability and the limited willingness of actors to share financial data. We defined a typical entity as a company or initiative with a large market share in organic seed production and, if existing, organic breeding. Typical economic entities were chosen as opposed to average entities to avoid aggregation bias. Here, again, the mode of the distribution of existing firms, as opposed to an artificial average firm, is identified [22]. Companies and initiatives that differ in size, target market, financing strategy for organic breeding can be observed. The firm with the most common combination of these criteria (mode) was chosen from these types.

\subsection{Data}

Typical farm data was collected through a series of stakeholder and expert interviews between 2017 and 2020. Data from the Italian and English Farm Accountancy Data Network (FADN) was reviewed and integrated, where appropriate (e.g., farm sizes and crop areas). Similarly, typical breeding and multiplication data were obtained through stakeholder and expert interviews between 2017 and 2020. An overview of the seed and breeding value chain landscape of Italian organic durum wheat and English organic perennial ryegrass production was obtained through a value chain mapping with the help of expert interviews.

In the case of Italy, this mapping revealed that several medium-sized companies and cooperatives are involved in providing seed for Italian organic durum wheat production. Two breeding and seed production companies shared detailed information on costs and revenues, inputs and outputs of durum wheat breeding and multiplication, as well as 
bottlenecks in seed production, promising breeding goals, and scenarios to boost the organic seed and breeding sector.

In the case of South-West England, the value chain actor mapping showed that around eight companies are involved in providing seed for organic ryegrass growers (sheep farms). These companies exhibit similar characteristics, so one typical company for the sector in England was identified [7]. The identified companies and initiatives were contacted for interviews. One internationally active breeding and seed production company with a significant market share in the UK in perennial ryegrass seed production shared detailed information on costs and revenues, inputs and outputs of breeding and multiplication, as well as bottlenecks in seed production, promising breeding goals, and scenarios to boost the organic seed and breeding sector.

\subsection{Case Study Description}

\subsubsection{Case 1, Durum Wheat in Italy}

Durum wheat was chosen as a case study focus crop since it is the key cereal crop produced in the Italian organic sector with an extensive production area. In Italy, most seed demand by organic farmers is met by untreated conventional seed, especially for the most widespread arable crops, particularly durum wheat. The major providers of seed and cultivars for the organic sector are international players, medium-sized breeding and seed producers that are most active in Italy, and, to a limited extent, public institutions. Farm saved seed plays a role as well as seed provision through farmers' associations [7]. The area of organic durum wheat production in Italy amounts to around 141,129 ha [23]. According to an estimate, about $40 \%$ of the organic farmers in Southern Europe declare to use their own seeds as a principal source of cereal seed for their farms [24]. More detailed data for the case of Italy and durum wheat was not available at the point of time of our data collection.

Farming: Based on the available data provided by the Italian (IT) Ministry of Agriculture, two farms were selected: one typical farm for Southern and Central Italy. Based on the available data provided by the Italian (IT) Ministry of agriculture, two main criteria were used to select regions and locations. First of all, the IT regions in which the major part of organic cereals is produced were identified. For this, regional distribution of organic land under cereal production (\%) was generated. Most of the organic cereal land is located in the Southern and Central parts of Italy, with three regions (Apulia, Sicily, and Basilicata) covering almost $50 \%$ of the total land dedicated to organic cereal in Italy. We also considered the regions with little organic cereal agricultural land but a high degree of specialisation in organic cereals production, which were identified based on the share of organic cereal in the total agricultural land (\%). The most critical regions are Basilicata, Sicily, Apulia, Marche, and Tuscany. Based on the results reported above, two main IT macro-regions were identified for our analysis: macro-region 1, which includes two neighbouring regions located in the Southern part of Italy (Apulia, Basilicata), and macro-region 2, which includes two regions in Central Italy (Marche and Tuscany). Once the macro-regions were identified, we explored three main parameters related to the production system: farm size, main enterprise, and farm performance. The chosen Southern Italian farm has a 60 ha total farm size. This is the typical size for the chosen region, it is however relatively large compared to Italian farms in other regions. The crop rotation is narrow: durum wheat, faba bean, durum wheat, chickpea, green manure, durum wheat. The share of durum wheat can reach up to $50 \%$ of the farm's agricultural area. The main marketing channel is selling to four or five big pasta manufacturers. In organic pasta production, one big company dominates the market, and there are also a few smaller organic pasta makers.

Regarding the Central farm type, the farm size is smaller and the crop rotation wider. The medium-sized farm is about 30 ha. The typical crop rotation includes alfalfa, emmer, faba bean, durum wheat, sunflower, soft wheat, clover, and chickpea. Land for durum wheat represents around 6 ha. The typical central farm type is more likely to be associated with cooperatives. There are two particularly successful cooperatives in encouraging 
organic seed use that have the following measures in place: (a) collective seed purchase reducing seed price, and (b) a pre-financing scheme where seed costs have to be paid only once the durum wheat has been sold. These measures increase farmers' liquidity. Other administrative burdens are also taken from farmers and organised collectively, such as choosing appropriate cultivars [25].

Seed multiplication: The organic arable seed sector is characterised by small to mediumsized companies that multiply organic seed and sell it to retailers or directly to farmers' cooperatives. In some cases, the same company also undertakes breeding, which is often observed for medium companies handling soft and durum wheat (examples can be found in Denmark, Germany, and Italy) [7].

The chosen company type for the simulation model for durum wheat seed production has the following profile according to the criteria defined in Section 2.3. The governance model is a shareholder-owned company, and its financing strategy for seed and breeding is re-financing its breeding activities through commercial seed sales. The target market is primarily national. Not chemically treated and chemically treated organic seed is produced. It has an integrated breeding department. More information on the seed production and breeding type can be found in Appendix B.1.

\subsubsection{Case 2, Perennial Ryegrass in England}

Forage crops (grass, clover, and herbal crops) represent an important crop sector in the UK, with temporary pasture being the second most important crop grown after permanent pasture, on about 92,000 ha and 330,000 ha, respectively [26]. The production of organic forage seed is limited in the United Kingdom. Most organic forage seed is imported from a few foreign companies operating internationally. Furthermore, organic breeding and breeding for organic in the forage sector is very limited. Conventional breeding is conducted by the private and public sectors alike.

In this case study, an intermediate product in the form of forage is investigated, meaning that there is no farm gate price of the product, i.e., perennial ryegrass, used to feed livestock. Changes in the farm-gate price for milk or meat or the price of alternative feed sources can be used to model farmers' decisions. In this case, we use the price for organic lamb meat. Ryegrass was considered and modelled in a less complex mixture with white clover, often used in England's rotational grazing. More information on the procedure can be found in Appendix B.2.

Farming: Farmers usually grow mixtures of several forage species and varieties, making it challenging to find organic seed for all the crop species and varieties needed in the mixture. We decided to focus on perennial ryegrass grown in a mixture with white clover since, based on expert interviews, perennial ryegrass is one of the most common grasses grown throughout the UK. It is most likely to find organic perennial ryegrass in the South West of England because of the high concentration of organic farms and pasture [26]. Therefore, the main counties considered are Devon, Dorset, Somerset, and Cornwall. The total organic grazing area in these four counties amounts to around 6000-7000 ha, and the number of organic sheep farms is about 500-600 with a total of 200,000 sheep [26]. We adopted an established system for this study to discriminate the grazing farming systems, which distinguished between lowland (LL) and upland (UL) grazing systems. The main differences between the two chosen typical sheep meat production systems are the following. The typical LL grazing system has a farm size of $88 \mathrm{ha}$, of which 81 ha is dedicated to grazing. It holds 73 grazing livestock units. The typical UL grazing system has a farm size of 194 ha, of which 176 ha is dedicated to grazing, holding 126 grazing livestock units. LL grazing systems have a higher seed need than UL grazing systems as they need to be re-planted every three years, whereas UL can be re-planted after five years. Furthermore, organic lamb meat produced in UL grazing systems can obtain a slightly higher price than lamb meat produced in an LL grazing system. Both systems are common in the chosen area and thus are represented in the simulation model. 
Seed multiplication: The company considered in this study for data collection and modelling for ryegrass seed production has the following profile according to the criteria defined in Section 2.3. The governance model is a shareholder-owned company, and its financing strategy for seed and breeding is re-financing of own breeding activities through commercial seed sales. The size of the company is large, and its target market is international. Not chemically treated and chemically treated organic seed is produced in the breeding department. More information on the seed production and breeding type can be found in Appendix B.2.

\subsection{Scenario Development}

Promising scenarios were identified during stakeholder interviews in the period of 2018 to 2019 and a workshop with organic crop experts for the respective cases for scenario development [7]. Scenario identification, assumptions, and data collection for scenarios were part of the stakeholder interview, as explained in more detail in Section 2.4. The chosen scenarios per case and the assumptions that are made are as follows:

Durum wheat:

- Stepwise phasing out of derogations for the use of non-organic seed at farm level (one-year steps) [Derog-Wheat].

- Organic durum wheat farm gate price premium per ton of organic seed use at farm (product) level [Prce-Wheat].

- Subsidy for organic seed use at farm (hectare) level [Subs-Wheat].

- Promoting organic farm-saved seed use [SavedS].

- Promoting the use of organic heterogeneous material $(\mathrm{OHM})$ and testing a price premium with the option to use OHM [OHM].

Perennial ryegrass:

- Stepwise phasing out of derogations for the use of non-organic seed at farm level (one-year steps) [Derog-Forage].

- Organic lamb meat farm gate price premium per $\mathrm{kg}$ for organic seed use at farm (product) level [Prce-Forage].

- Subsidy for organic seed use at farm (hectare) level [Subs-Forage].

- Breeding goal " $10 \%$ organic seed yield increase": Investment in breeding for higher nitrogen efficiency at perennial ryegrass seed production level, e.g., funded through a public-private partnership [HseedY].

For each scenario, some assumptions were made, as shown in Tables 1 and 2 below:

Table 1. Scenarios and assumptions of Case 1.

\begin{tabular}{|c|c|c|}
\hline \multicolumn{2}{|r|}{ Scenario } & \multirow[t]{2}{*}{ Assumptions } \\
\hline 1. & Baseline [Bsl-Wheat] & \\
\hline 2. & $\begin{array}{l}\text { Stepwise phasing out of derogations } \\
\text { at farm level to use organic seed } \\
\text { [Derog-Wheat] }\end{array}$ & $\begin{array}{c}\text { Adaptive expectations mechanism: } \\
\text { Growth expectation factor equals } 3 \\
\text { Stepwise phasing out of derogations for NCT seed } \\
\text { Yearly steps: Year 1: 80\% NCT seed allowed per farm, year 2: } \\
\text { 50\%, year 3: } 30 \% \text {, year 4: } 0 \%\end{array}$ \\
\hline 3. & $\begin{array}{l}\text { Organic durum wheat farm gate } \\
\text { price premium per ton for organic } \\
\text { seed use [Prce-Wheat] }\end{array}$ & $\begin{array}{c}\text { Adaptive expectations mechanism: } \\
\text { Growth expectation factor equals } 3 \\
\text { Different levels of price premiums are tested. The goal of this } \\
\text { process was to identify price premium levels that induce farm } \\
\text { agents to adopt organic seed }\end{array}$ \\
\hline 4. & $\begin{array}{l}\text { Subsidy for organic seed use at farm } \\
\text { (ha) level [Subs-Wheat] }\end{array}$ & $\begin{array}{c}\text { Adaptive expectations mechanism: } \\
\text { Growth expectation factor equals } 3 \\
\text { Different levels of subsidies are tested. The goal of this process } \\
\text { was to identify subsidy levels that induce farm agents to adopt } \\
\text { organic seed }\end{array}$ \\
\hline
\end{tabular}


Table 1. Cont.

\begin{tabular}{|c|c|c|}
\hline \multicolumn{2}{|r|}{ Scenario } & Assumptions \\
\hline 5. & $\begin{array}{l}\text { Promoting organic farm saved seed } \\
\text { use [Bsl-Wheat }+[\text { SavedS] }\end{array}$ & $\begin{array}{c}\text { Own seed production at farm level is possible with a seed } \\
\text { replacement rate of } 0.3\end{array}$ \\
\hline 6. & $\begin{array}{l}\text { Scenario } 2 \text { and } 5 \\
{[\text { Derog-Wheat }]+[\text { SavedS }]}\end{array}$ & No new assumptions \\
\hline 7. & $\begin{array}{l}\text { Scenario } 3 \text { and } 5 \\
{[\text { Prce-Wheat }]+[\text { SavedS }]}\end{array}$ & No new assumptions \\
\hline 8. & $\begin{array}{l}\text { Scenario } 4 \text { and } 5 \\
{[\text { Subs-Wheat }]+[\text { SavedS }]}\end{array}$ & No new assumptions \\
\hline 9. & $\begin{array}{l}\text { Promoting organic farm } \\
\text { saved seed use in OHM } \\
{[\text { Bsl-Wheat }]+[\text { SavedS }]+[\text { OHM }]}\end{array}$ & $\begin{array}{l}\text { Own OHM seed production at farm level is possible with a } \\
\text { seed replacement rate of } 0.3\end{array}$ \\
\hline 10. & $\begin{array}{l}\text { Scenario 3, } 9 \text { and } 12 \\
{[\text { Prce-Wheat }]+[\text { SavedS }]+[\mathrm{OHM}]}\end{array}$ & No new assumptions \\
\hline
\end{tabular}

The unique scenario names are bold and in italics.

Table 2. Scenarios and assumptions of Case 2.

\begin{tabular}{|c|c|c|}
\hline \multicolumn{2}{|r|}{ Scenario } & \multirow[t]{2}{*}{ Assumptions } \\
\hline 1. & Baseline [Bsl-Forage] & \\
\hline 2. & $\begin{array}{l}\text { Stepwise phasing out of } \\
\text { derogations at farm level to use } \\
\text { organic seed [Derog-Forage] }\end{array}$ & $\begin{array}{c}\text { Adaptive expectations mechanism: } \\
\text { Growth expectation factor equals } 2 \\
\text { Stepwise phasing out of derogations for NCT seed } \\
\text { Yearly steps: Year 1: 80\% NCT seed allowed per farm, year 2: } \\
\text { 50\%, year 3: 30\%, year 4: } 0 \%\end{array}$ \\
\hline 3. & $\begin{array}{l}\text { Organic lamb meat farm gate } \\
\text { price premium for organic seed } \\
\text { use [Prce-Forage] }\end{array}$ & $\begin{array}{l}\text { Adaptive expectations mechanism: } \\
\text { Growth expectation factor equals } 2 \\
\text { Different levels of price premiums are tested. The goal of this } \\
\text { process was to identify price premium levels that induce farm } \\
\text { agents to adopt organic seed }\end{array}$ \\
\hline 4. & $\begin{array}{l}\text { Subsidy for organic seed use at } \\
\text { farm (ha) level [Subs-Forage] }\end{array}$ & $\begin{array}{c}\text { Adaptive expectations mechanism: } \\
\text { Growth expectation factor equals } 2 \\
\text { Different levels of subsidies are tested. The goal of this process } \\
\text { was to identify subsidy levels that induce farm agents to adopt } \\
\text { organic seed }\end{array}$ \\
\hline 5. & $\begin{array}{l}\text { Condition "10\% organic } \\
\text { seed yield increase" } \\
\text { [Bsl-Forage] + [HseedY] }\end{array}$ & $\begin{array}{l}\text { Farm level: Seed price reduction of } 8.7 \% \text { for the organic mixture } \\
\text { Multiplication level: Accomplishment of } 10 \% \text { seed yield increase } \\
\text { of organic perennial ryegrass seed as a breeding goal }\end{array}$ \\
\hline 6. & $\begin{array}{l}\text { Scenario } 2 \text { and } 5 \\
{[\text { Derog-Forage }]+[\text { Heed } Y]}\end{array}$ & No new assumptions \\
\hline 7. & $\begin{array}{l}\text { Scenario } 3 \text { and } 5 \\
{[\text { Prce-Forage }]+[\text { Hseed }]}\end{array}$ & No new assumptions \\
\hline 8. & $\begin{array}{l}\text { Scenario } 4 \text { and } 5 \\
{[\text { Subs-Forage }]+[\text { Hseed } Y]}\end{array}$ & No new assumptions \\
\hline
\end{tabular}

The unique scenario names are bold and in italics.

\section{Results}

The modelled organic crop area is held constant over the eight years modelled so that effects of interventions can be compared to the baseline without having to account for crop area increase. Thus, the effects of a growing organic area are excluded from the following results presented.

The results on gross margins and breeding budgets presented in this section are calculated from the last three years modelled (years six to eight). The organic seed amounts indicated are also the averages of these years.

The levels of subsidies and price premiums were calculated in an iterative process of simulation model results. This process aimed to identify subsidy and price premium levels that would lead farm agents to adopt organic seed or cultivars. 


\subsection{Modelling Results of Case 1, Durum Wheat in Italy}

Scenario 1: Baseline.

We use a simplified model including only two farm agents. Thus, we implemented a baseline of zero organic seed use for both farm agents. This represents the majority of farms, as around $65 \%$ NCT seed is used across the farm population of the overall seed use. The average yearly gross margins (GM) at the farm enterprise level is $€ 26,528$, the yearly average gross margin at multiplication level for conventional untreated seed (seed production only, excluding processing and marketing, etc.) is $€ 247,208$, and the average yearly breeding budget for durum wheat is $€ 248,477$. These figures are close to the figures collected from the companies and thus act as realistic baseline values to compare scenario outcomes. In Table 3, the results of different scenarios can be seen relative to the baseline.

Table 3. Summary of results using key outcome variables for Case 1.

\begin{tabular}{|c|c|c|c|c|c|c|}
\hline & $\begin{array}{c}\% \Delta \\
\text { GM/Farm } \\
\text { Enterprise }\end{array}$ & $\begin{array}{c}\% \Delta \mathrm{GM} / \text { Seed } \\
\text { prod. org. Seed } \\
\text { and NCT Seed }\end{array}$ & $\begin{array}{c}\% \Delta \text { Breeding } \\
\text { Budget Organic, } \\
\text { NCT and CT Seed }\end{array}$ & $\begin{array}{c}\% \Delta \\
\text { Organic } \\
\text { Seed Use }\end{array}$ & $\begin{array}{c}\text { Costs of } \\
\text { Intervention } \\
\text { in } €\end{array}$ & $\begin{array}{c}\text { Cost Effectiveness } \\
\text { (Ton Organic } \\
\text { Seed/€) }\end{array}$ \\
\hline Scenarios (\#) & Mean & Mean & Mean & Mean & Mean & Mean \\
\hline \multicolumn{7}{|l|}{$\begin{array}{l}\text { Without farm } \\
\text { saved seed }\end{array}$} \\
\hline $\begin{array}{c}\text { Stepwise } \\
\text { phasing out of } \\
\text { derogation (2) }\end{array}$ & $-1.54 \%$ & $14.82 \%$ & $10.44 \%$ & $100.00 \%$ & $\mathrm{n} / \mathrm{a}$ & $\mathrm{n} / \mathrm{a}$ \\
\hline $\begin{array}{l}\text { Organic seed } \\
\text { price } \\
\text { premium } \\
(12 € / t)(3)\end{array}$ & $5.75 \%$ & $15.87 \%$ & $10.44 \%$ & $100.58 \%$ & $2,465,428.62$ & 0.01 \\
\hline $\begin{array}{c}\text { Subsidy } \\
(28 € / \text { ha })(4)\end{array}$ & $21.19 \%$ & $17.76 \%$ & $10.23 \%$ & $101.12 \%$ & $1,937,063.92$ & 0.01 \\
\hline \multicolumn{7}{|c|}{ Farm saved seed with a 3 year replacement rate with organic seed } \\
\hline $\begin{array}{c}\text { Stepwise } \\
\text { phasing out of } \\
\text { derogation (6) }\end{array}$ & $-2.52 \%$ & $10.38 \%$ & $10.44 \%$ & $98.23 \%$ & $\mathrm{n} / \mathrm{a}$ & $\mathrm{n} / \mathrm{a}$ \\
\hline $\begin{array}{l}\text { Organic seed } \\
\text { price } \\
\text { premium } \\
(0.3 € / t)(7)\end{array}$ & $0.47 \%$ & $9.33 \%$ & $10.39 \%$ & $99.24 \%$ & $63,848.18$ & 0.24 \\
\hline $\begin{array}{c}\text { Subsidy } \\
(15 € / \text { ha })(8)\end{array}$ & $0.47 \%$ & $9.33 \%$ & $10.39 \%$ & $99.24 \%$ & $63,848.18$ & 0.24 \\
\hline \multicolumn{7}{|c|}{ Introducing $\mathrm{OHM}$ as innovation } \\
\hline $\begin{array}{l}\text { OHM price } \\
\text { premium on } \\
\text { durum wheat } \\
\text { with own } \\
\text { farm saved } \\
\text { seed use } \\
(13 € / \text { ton) (9) }\end{array}$ & $18.99 \%$ & $110.77 \%$ & $13.86 \%$ & $96.67 \%$ & $1,152,591.70$ & 0.01 \\
\hline
\end{tabular}

Scenario 2: Command and control approach to derogation phasing out.

If derogations were to be phased out in three steps (Year 1: 80\% NCT seed allowed per farm, year 2: $50 \%$, year 3: $30 \%$, year 5: $0 \%$ ), the farmers would still have to bear the burden of additional seed costs. This would cause an average 1.5\% loss in gross margin at the farm enterprise level. If $100 \%$ organic seed is achieved, the typical seed producer has 
an increase in gross margin by $15 \%$ and the breeding department by $10 \%$. The estimated development of the organic durum wheat seed taken up under such a derogation scheme can be seen in Figure 2. The results shown in this figure are scaled up to the regional level and therefore need to be considered cautiously, as we only modelled the decision-making of the two typical farms.

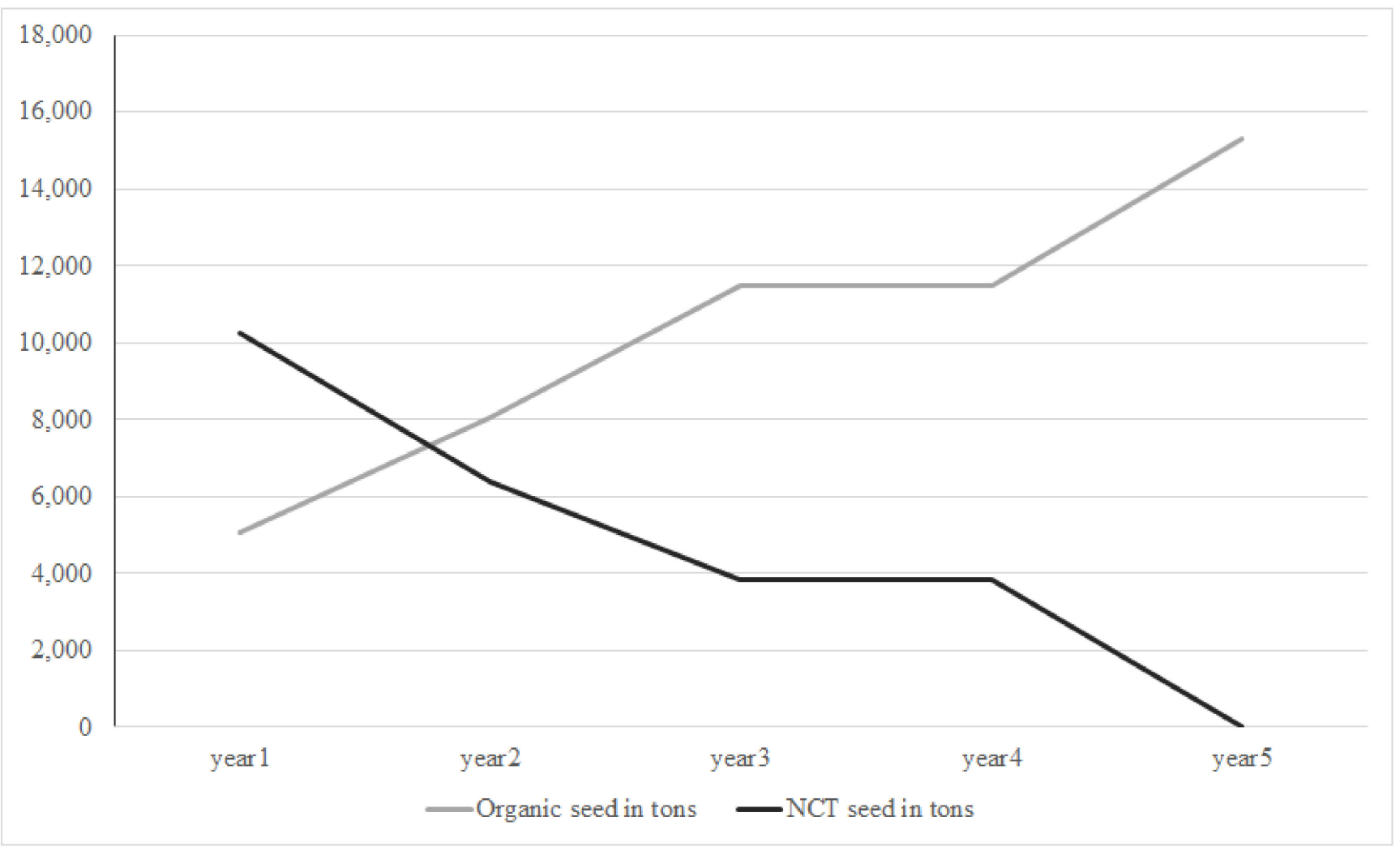

Figure 2. Scenario 2: Development of organic seed use in a modelling period of five years under a stepwise phasing out of a derogations scheme.

Scenarios 3 and 4: Voluntary measures to incentivise organic farmers to use organic seed. Measures to support farmers to bear the additional costs for organic seed in the short term can be increasing farm-gate prices or providing farm subsidies. The outcomes of these scenarios can be seen in Table 3, rows 2 and 3 . With a $€ 12$ increase per ton of organic durum wheat sold, both farm types would be compensated for the additional seed costs.

The same effects along with the durum wheat seed and breeding value chain are obtained with an area subsidy for using organic seed of $€ 28$ per hectare for both farm types. Regarding the cost-effectiveness of these interventions, on average, $7.7 \mathrm{~kg}$ per $€$ subsidy can be incentivised, up to $100 \%$ organic seed use by both farm agents considered here.

These measures could smooth a transition to $100 \%$ organic durum wheat use. There are no losses because of seed shortages. According to the expert interviewed, organic durum wheat seed production is not substantially restrained by technical difficulties. However, some time needs to be allowed to find suitable varieties for organic agriculture, so an immediate $100 \%$ phasing out is not advisable.

Scenario 5: Farm saved organic seed.

Farm saved seed is an essential part of the strategy to obtain $100 \%$ organic seed. This is especially relevant in crops where farmers' own seed production is relatively straightforward, such as many kinds of cereal. However, pests and diseases like smut in cereals pose some challenges for on-farm seed production. Training for own seed production, pest management, and promotion of smut-resistant cultivars should be considered. On-farm seed production represents a realistic option to decrease costs for farmers and boost organic 
seed use. If appropriate measures are taken, farmers would have the know-how to manage pests and diseases and the necessary processing and storage facilities.

Within the model, if the two typical farms are given the option to produce and use farm-saved seed, both types produce their own seed. As we assumed a seed replacement rate of around 0.33 (see Table 1), the typical farms buy the necessary seed from the seed and breeding actors, choosing NCT seed. The average yearly gross margin (GM) at the farm enterprise level is $€ 26,695$, which is slightly higher than the baseline value without the option to use and produce farm-saved seed. The yearly average gross margin at multiplication level for conventional untreated seed (seed production only, excluding processing and marketing, etc.) is $€ 247,208$, and the average yearly breeding budget for durum wheat is $€ 248,477$. These figures are close to the figures collected from the companies during interviews. The figures are thus realistic baseline values against which scenario outcomes can be compared.

Scenario 6: Command and control approach for non-organic seed use with the option for the farmer to save own seed (farm-saved seed).

If derogations were to be phased out in three steps (Year 1: 80\% NCT seed allowed per farm, year 2: $50 \%$, year 3: $30 \%$, year 5: $0 \%$, the farmers would have to bear the burden of additional seed costs, which would amount to an average of $2.5 \%$ loss in gross margin at the farm enterprise level. Even though this loss through organic seed use is bigger in percentage than the loss through organic seed use without own seed production, the total gross margin is nevertheless higher with own seed production. If $100 \%$ organic seed is obtained, the typical seed producer and the breeding department both have a 10\% increase in gross margin.

Scenarios 7 and 8: Voluntary measures to incentivise organic farmers to use organic seed when promoting farm-saved seed with organic seed.

Measures to support farmers with the additional costs in the short term can be increasing product prices or providing farm subsidies. The outcomes of these scenarios can be seen in Table 3, rows 5 and 6 . With a $€ 0.3$ increase per ton of organic durum wheat sold, the farms would be compensated for the additional seed costs.

The same effects along with the durum wheat seed and breeding value chain could be obtained with subsidies for using organic durum wheat basic seed and producing their own organic seed of $€ 15$ per hectare for both farm types. Regarding the cost-effectiveness of these interventions, 0.24 tons per $€$ subsidy on average can be incentivised up to $100 \%$.

Scenario 9: Introduction and promotion of Organic Heterogeneous Material and farm-saved seed.

A further proposed intervention is the encouragement to use organic heterogeneous material (OHM). OHM is broadly defined in the New Organic Regulation 2018/848/EU as 'material with a high level of genetic diversity, intended for the market and for which DUS criteria (Distinctness, Uniformity, and Stability) are not applicable (New Organic regulation 848/2018). OHM is generally more resilient in low input systems, as there is high yield stability and fertilisers are unnecessary. According to our case study data collection, however, overall yields associated with OHM are $10 \%$ lower than the yield of prevalent non-OHM cultivars. It is supposed that farmers choosing OHM would save their own seed for re-planting. Furthermore, it seems most realistic that a price premium for OHM seed use would be implemented by a trader or a cooperative instead of a subsidy implemented by the government. The results from the modelling of this scenario in Table 3, row 7 show that, if farmers were to produce OHM seed themselves, a price premium for OHM durum wheat of $€ 12$ per ton (with a seed replacement rate of 0.3 ) would be sufficient to incentivise farmers to use OHM seed. For seed producers, this would mean a substantial increase in gross margin (Table 3, row 7, column 2), which makes producing OHM seed quite attractive if the two typical farms are incentivised to grow OHM through the price premium. In Figure 3, the GMs at the farm level across all scenarios can be seen. 


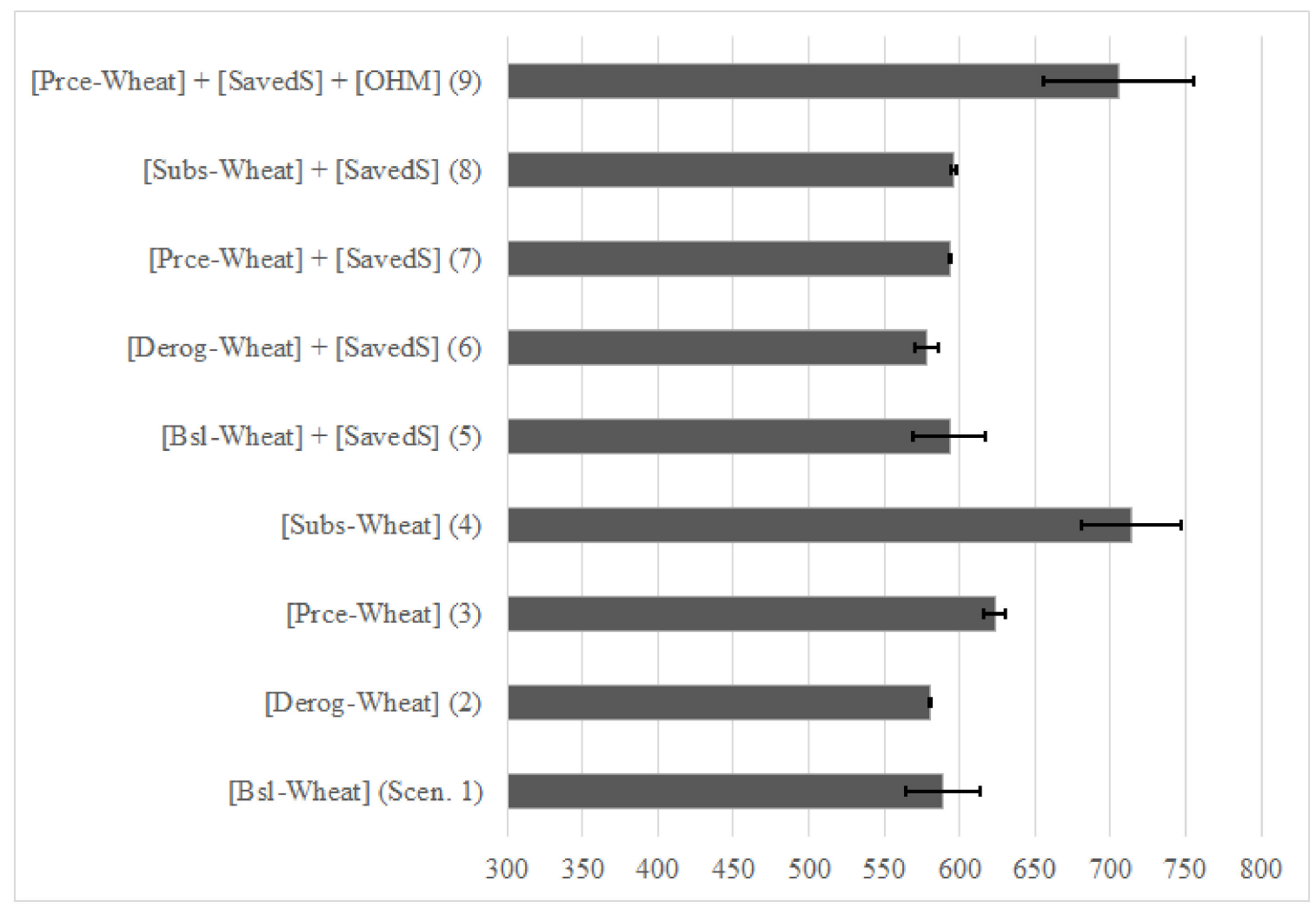

Figure 3. Average gross margins in $€$ per ha and confidence intervals (95\%) calculated by sensitivity analysis (ten model runs with triangular distributions over yields in ton/ha and farm gate prices $€ /$ ton at farm level).

\subsection{Modelling Results of Case 2, Perennial Ryegrass in England}

Scenario 1: Baseline.

In the baseline scenario, none of the simulated actors produce or use organic seed. The average yearly gross margin at the farm enterprise level is $€ 48,410$. The gross margin at multiplication level for conventional untreated seed (seed production only, excluding processing and marketing, etc.) is $€ 28,577,976$, and the breeding budget for perennial ryegrass is $€ 1,013,487$. These figures are close to the figures obtained during data collection and are therefore acceptable as baseline values.

Scenario 2: Command and control approach to derogation phasing out.

In Table 4, the results of different scenarios can be seen relative to the baseline. As shown in the first row of Table 4, if derogations were to be phased out in three steps (Year 1: $80 \%$ NCT seed allowed per farm, year 2: $50 \%$, year 3: $30 \%$, year 5: $0 \%$ ), the farmers would have to bear the burden of additional seed costs, which would amount to an average of $7 \%$ loss in gross margin. If $100 \%$ organic seed use is achieved, the typical seed producer increases gross margin by $23.5 \%$ and the breeding department by $13.7 \%$. This shows that producing organic seed for perennial ryegrass can be an attractive business opportunity if seed usage is controlled by regulatory instruments such as a mandatory phasing out of derogations (even with a stepwise approach). The estimated development of the 70\% organic seed mixture taken up under such a derogation scheme can be seen in Figure 4. The results shown in this figure are scaled up to region level.

Scenarios 3 and 4: Voluntary measures incentivising farmers to use organic seed.

Measures to support farmers to afford the additional seed costs in the short term can be increasing farm-gate prices or providing farm subsidies. As indicated in rows two and three of Table 4, with a 6-pence price increase of lamb meat, both farm types would be compensated for the higher seed price, leading to an approximate $90 \%$ increase in organic seed use. The same effects along with the perennial ryegrass seed and breeding value chain can be achieved with an area subsidy of $€ 13$ per hectare for both farm types for $70 \%$ organic 
seed use in the mixture containing white clover and perennial ryegrass. With a $€ 1$ subsidy or higher product price, 1.62 tons organic mixture can be incentivised up to $90 \%$ of the entire pasture area (rows 2 and 3, column 7).

Table 4. Summary of results using key outcome variables for case studies.

\begin{tabular}{|c|c|c|c|c|c|c|}
\hline & $\begin{array}{c}\% \Delta \\
\text { GM/Farm } \\
\text { Enterprise }\end{array}$ & $\begin{array}{l}\% \Delta \mathrm{GM} / \text { Seed } \\
\text { prod. org. Seed } \\
\text { and NCT Seed }\end{array}$ & $\begin{array}{c}\% \Delta \text { Breeding } \\
\text { Budget Organic, } \\
\text { NCT and CT Seed }\end{array}$ & $\begin{array}{c}\% \Delta \\
\text { Organic } \\
\text { Seed Use }\end{array}$ & $\begin{array}{l}\text { Costs of In- } \\
\text { tervention } \\
\quad \text { in } €\end{array}$ & $\begin{array}{c}\text { Cost Effectiveness } \\
\text { (Ton Organic } \\
\text { Seed/€) }\end{array}$ \\
\hline Scenarios (\#) & Mean & Mean & Mean & Mean & Mean & Mean \\
\hline $\begin{array}{c}\text { Stepwise } \\
\text { phasing out of } \\
\text { derogation (2) }\end{array}$ & $-6.61 \%$ & $23.54 \%$ & $13.68 \%$ & $100 \%$ & $\mathrm{n} / \mathrm{a}$ & $\mathrm{n} / \mathrm{a}$ \\
\hline $\begin{array}{l}\text { Organic seed } \\
\text { price premium } \\
(0.07 € \text { per kg } \\
\text { lamb) (3) }\end{array}$ & $34.91 \%$ & $21.18 \%$ & $12.31 \%$ & $90 \%$ & 62,634 & 1.62 \\
\hline $\begin{array}{c}\text { Subsidy } \\
(13 € / \text { ha })(4)\end{array}$ & $34.91 \%$ & $21.18 \%$ & $12.31 \%$ & $90 \%$ & 62,634 & 1.62 \\
\hline
\end{tabular}

Higher nitrogen efficiency $10 \%$ organic seed yield increase at multiplication level (and then translated into a lower seed price at farm level)

\begin{tabular}{|c|c|c|c|c|c|c|}
\hline $\begin{array}{l}\text { Without further } \\
\text { intervention (5) }\end{array}$ & $0.00 \%$ & $0.00 \%$ & $0.00 \%$ & $0 \%$ & $\mathrm{n} / \mathrm{a}$ & $\mathrm{n} / \mathrm{a}$ \\
\hline $\begin{array}{c}\text { Stepwise } \\
\text { phasing out of } \\
\text { derogation (6) }\end{array}$ & $-3.33 \%$ & $10.61 \%$ & $11.09 \%$ & $100 \%$ & $\mathrm{n} / \mathrm{a}$ & $\mathrm{n} / \mathrm{a}$ \\
\hline $\begin{array}{l}\text { Organic seed } \\
\text { price premium } \\
(0.04 € \text { per kg } \\
\text { lamb) (7) }\end{array}$ & $21.36 \%$ & $10.61 \%$ & $11.09 \%$ & $90 \%$ & 33,930 & 2.99 \\
\hline $\begin{array}{c}\text { Subsidy } \\
(6 € / \text { ha) }(8)\end{array}$ & $21.36 \%$ & $10.61 \%$ & $11.09 \%$ & $90 \%$ & 33,930 & 2.99 \\
\hline
\end{tabular}

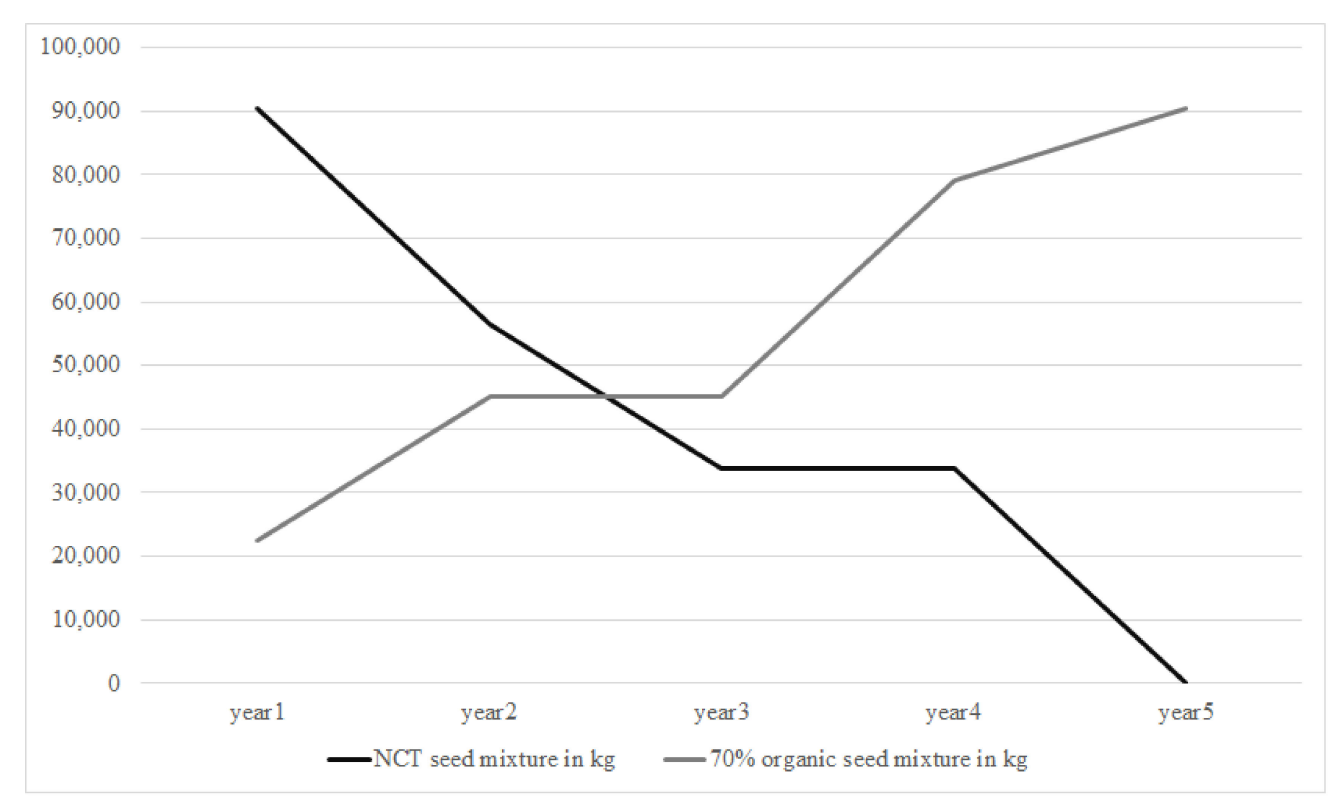

Figure 4. Scenario 2: Development of organic seed use in a modelling period of five years under a stepwise phasing out of derogations scheme. 
These measures would smooth the transition to $70 \%$ of organic seed use in $100 \%$ of the seed mixtures purchased and sown by the organic farmers in the region considered. No substantial losses are expected because of seed shortages, according to the experts interviewed. In the used mixture, only perennial ryegrass must be organic, and only $70 \%$ of it. Ryegrass makes up $87.5 \%$ of the entire mixture. Compared to other crops such as many vegetable crops, perennial ryegrass seed production seems less restrained by technical difficulties. The typical seed producer and breeder are expected to achieve a gross margin increase of around $20 \%$.

Scenarios 5 to 8: Higher nitrogen efficiency in the seed multiplication stage as a breeding goal.

In order to find solutions for the longer term, seed yield increase through improved nitrogen utilisation at seed production level was identified as a key breeding goal (Condition: "10\% organic seed yield increase"). This could have the effect of reducing organic seed prices. The results of these scenarios are in Table 4 , rows 4 to 7 .

Regarding the financing strategy for such a breeding program, Switzerland has one example of a public-private partnership that makes it possible to pursue breeding goals specifically for organic agriculture. Based on expert interviews, we assume that improved nitrogen utilisation at the seed multiplication stage would bring about a $10 \%$ organic seed yield increase, a price reduction of organic seed mixture at farm level of $8.7 \%$, and a $10 \%$ reduction for organic ryegrass seed price (revenue per seed) at the multiplication level. As the resulting price reduction of $8.7 \%$ would not be sufficient to lead farmers to adopt organic seed use voluntarily, some policy schemes are justified.

In this scenario, a phasing out of derogations would only amount to a loss of around $3.3 \%$ in gross margin at the farm level. The gross margin and breeding budget would increase less than without this investment in breeding, but still, they would increase substantially.

If the breeding goals were successfully implemented, the farm subsidy and price premium to achieve $90 \%$ organic seed use would be substantially lower than the other scenarios, corresponding to $€ 6$ per ha or 4 cents per $\mathrm{kg}$ of lamb meat. The measures would be approximately twice as cost-effective as the measures without the seed yield increase. In Figure 5, an overview is provided of the average farm enterprise gross margins per ha and year across the scenarios. Regarding the seed producer, there is still an increase of around $10 \%$ in their gross margin with the reduced seed price.

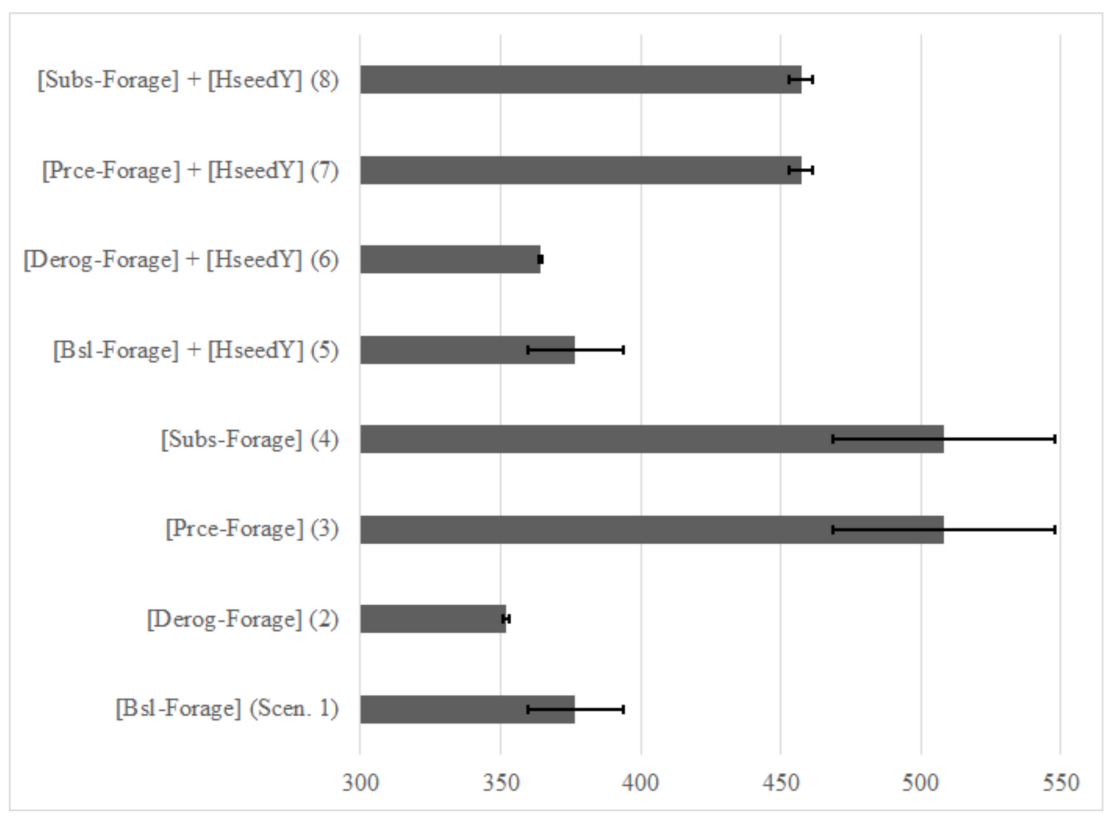

Figure 5. Average gross margins in $€$ per ha and confidence intervals (95\%) calculated by sensitivity analysis (Ten model runs with triangular distributions over lamb prices in $€ /$ ha at farm level). 


\section{Discussion}

Organic durum wheat model: According to our results relating to the organic durum wheat case study in Italy, phasing out of derogations within a few years seems to be a realistic policy goal. Seed companies would likely be able to supply a sufficient amount of organic seed. Nevertheless, a former study [7] emphasises that some time is likely to be necessary for the transition to find suitable cultivars for different climatic conditions and soil types. Therefore, derogations should be phased out gradually. Furthermore, farmers should be supported in farm seed production. Measures providing farmers with training for their own seed production, pest management, and the promotion of smut-resistant cultivars are recommended to support the transition to $100 \%$ organic seed use [7]. If farmers can produce at least part of their own seed need, $100 \%$ organic seed, or nearly $100 \%$, can be achieved without substantial loss in gross margins at the farm enterprise level $(2.5 \%$ on average if farmers produce with a 0.3 seed replacement rate). Moreover, a subsidy of $€ 15$ per hectare of durum wheat to incentivise own organic seed production could support the transition further. In both Southern and Northern Italian farm types, the current level of subsidies for durum wheat ranges from a minimum of $€ 220$ per hectare to a maximum of $€ 258$ per hectare $[27,28]$.

Some studies argued that the use of OHM could be a promising way to move towards organically bred cultivars well suited for organic agriculture. OHM has high yield stability and a low external input need, which is advantageous in low input farming systems and is particularly suited for climate change adaptation $[9,10]$. However, it is likely that the approach used in this study does not show all the possible advantages of OHMs as only two farms of an average to high productivity are examined in accordance with the Agribenchmark approach [20]. The advantages of OHM are likely to be seen more clearly if farms in more marginal regions and consequently of lower productivity were considered. As yields are somewhat lower on average in the investigated typical farms, the uptake at the farm level would need to be incentivised with a price premium for durum wheat OHM of $€ 13$ per ton if farmers produced most of their own OHM seed. Implementing such a measure at the cooperative level seems more realistic, as cooperatives in the sector are widespread in Italy, and there are already examples where they promote the use of particularly suitable cultivars and seed types.

According to our modelling results, the investigated organic durum wheat seed multiplier can increase their gross margin by $9-18 \%$ if they produced organic seed as opposed to NCT seed and by $110 \%$ if they produced OHM seed as opposed to NCT seed. However, definite political commitment to increasing organic seed use is critical for seed producers [29]. Next to policies at the country level, promoting cooperation or POs are promising policy instruments to induce farmers to use organic seed and cultivars and induce breeders to breed for organic agriculture [30]. Furthermore, some medium-sized breeding companies have taken up OHM breeding, indicating that this could be a way forward for more breeding for the organic sector. It seems to be a profitable business branch for seed producers if demand at the farm level is stimulated.

Organic perennial ryegrass model: Implementing a farm subsidy of $€ 13$ per ha of pasture would encourage farmers to start using organic seeds for perennial ryegrass voluntarily in the short-term, covering the additional costs for organic seeds. Phasing out of derogations would substantially increase costs for organic lamb producers, on average by $6.6 \%$. In the longer term, the inclusion of a seed yield increase as a breeding goal of around $10 \%$ is recommended to reduce organic seed costs by $50 \%$.

According to expert estimations, perennial ryegrass seems to be sufficient availability or at least the capacity to produce enough organic seed. However, an identified difficulty seems to exist concerning the rest of the grass mixture. Clovers may also still be sufficiently available, but there is a trend towards more diversified mixtures that are more resilient than simpler mixtures in terms of climate robustness or similar issues [31]. With very small shares in the mixtures of some crop species and cultivars, financing organic seed production and breeding activities for minor crops would be a challenge. Consequently, 
there is a trade-off between obtaining $100 \%$ organic seed in forage mixtures and resilient grazing systems. At least for the short to middle term, a solution is to continue allowing 70 to $90 \%$ of organic seed in the mixture. According to our modelling results, the investigated organic perennial ryegrass seed multiplier can increase their gross margin by $21-24 \%$ if they produced organic seed as opposed to NCT seed.

A public-private partnership like that in place in Switzerland could be a promising approach to fund organic breeding for perennial ryegrass and other components in forage seed mixtures. This financing strategy could facilitate achieving breeding goals, such as a higher nitrogen efficiency, as was modelled in this study. In this financing model, costs and tasks are shared by a public institution and a medium-sized seed company [32]. It could further be important if organic breeding for crops with a very small share in the seed mixtures should be taken up. In general, an increase in public investment in organic plant breeding seems advisable. Other promising financing strategies that have been identified for organic breeding, such as a value chain pool funding financed by the food industry, or funding by cooperative structures, rely heavily on the voluntary engagement of value chain actors [33] and are thus uncertain.

Some limitations of this study need to be mentioned. In the baseline, none of the simulated actors produce or use organic seed. Selling organic seed would be more profitable for the seed company; however, there is no demand on the farm side. Thus, the seed company does not produce any organic seed. This does not reflect the actual situation, as around $35 \%$ of organic seed use by organic durum wheat producers has been estimated in Italy. However, the simplified model structure does not allow for calibration according to organic seed use across the farm population, as only two farms are considered. The simplified model structure needed to be adopted due to data limitations. Such a calibration could be conducted if the entire farm population was modelled [6]. Furthermore, although the decision-making of all typical actors in the seed and breeding value chain is captured, the model cannot depict much heterogeneity at the different levels. This could be solved by including a full agent-based approach where all actors are modelled individually. However, this is only possible where a high level of detail in data is available, which was not the case in this study. Constant market size and distributions of yields and prices over the modelling period are further simplifications. This means that possible external market effects or unexpected shocks are not considered in the study. As these effects are challenging to predict with any reasonable certainty and beyond the research interest, they are disregarded for the sake of parsimony.

To the best of our knowledge, this is one of the first studies to integrate all three levels of the seed value chain (farming, seed multiplication, and breeding) for the organic sector into one consistent optimisation-based simulation model. The results of this study are particularly relevant as the New Organic Regulation 848/2018, which enters into force in 2022, and derogations for the use of non-organic seed in Europe are planned to be phased out by 2036. This is the first study to systematically analyse the consequences of these planned interventions in the necessary degree of detail. Moreover, to be able to realise ambitious policy goals, as formulated in the farm to fork strategy, where a $25 \%$ increase of the organic agricultural land share is the aim by 2030 [1], the availability and use of organic seed must be considered essential [29].

\section{Conclusions}

Our modelling study proves that the phasing out of derogations for the use of NCT causes gross margin losses at the farm level, however, the gross margins remain positive in the two case studies investigated. At the same time, an increase in gross margin at seed production and breeding levels can be observed in both cases. The extent of these losses or gains differs based on several factors such as seed price of the crop and cultivar, and how difficult producing seeds under organic conditions is. For example, seed companies could incur losses with seeds that are more difficult to produce organically than wheat or ryegrass. An example of this is represented by wash/storage carrots in Germany, where 
we conducted a similar study using the same modelling approach [6]. Overall, as results are very much crop and country-dependent, future research based on case studies that take these unique aspects into account is valuable in developing a roadmap to increase organic seed use.

Another important conclusion of our study is that a combination of public interventions is justified and needed to smooth the transition to increased organic seed use. The market alone is not likely to deliver $100 \%$ organic seed use. Amongst the public interventions that we looked at, the provision of farm subsidies is advisable to compensate farmers for their losses. The support of farm-saved seed through training and research in breeding is also recommended to improve organic seed production and supply capacity. From a market perspective, a price premium can help farmers bear the additional costs of organic seeds. However, price premiums are subject to a willingness to pay by the downstream actors and are therefore recommended in association with the voluntary use of organic cultivars and private labels. To the best of our knowledge, this study is the first to analyse the economic performance of typical seed and breeding value chains in two case studies with a novel multi-agent value chain approach. The results of this study furnish evidence-based insights into changes resulting from planned policy interventions in the rapidly growing organic sector.

Author Contributions: Conceptualization, E.W., C.G. and J.A.; methodology, E.W., C.G. and J.A.; software, E.W. and J.A.; validation, E.W. and J.A.; data curation, E.W., S.O. and F.S.; writing—original draft preparation, E.W.; writing—review and editing, S.O., C.G., F.S. and J.A.; visualization, E.W.; supervision, C.G. and J.A.; project administration, S.O. and C.G. All authors have read and agreed to the published version of the manuscript.

Funding: Work was conducted in scope of the Collaborative Project LIVESEED: “Improving the performance of organic agriculture by boosting organic seed and plant breeding efforts across Europe" which is supported by the European Union's HORIZON 2020 research and innovation programme under the Grant Agreement no 727230, and by the Swiss State Secretariat for Education, Research and Innovation (SERI) under contract number 17.0009.

Acknowledgments: The authors would like to thank Monika M. Messmer for her support.

Conflicts of Interest: The authors declare no conflict of interest. The funders had no role in the design of the study; in the collection, analyses, or interpretation of data; in the writing of the manuscript, or in the decision to publish the results.

Disclaimer: The opinions expressed and arguments employed herein do not necessarily reflect the official views of the EC and the Swiss government. Neither the European Commission/SERI nor any person acting behalf of the Commission/SERI is responsible for the use which might be made of the information provided in this study.

\section{Appendix A}

Table A1. Wheat case: Farm gate prices in $€ /$ ton (Modi, minima, maxima) used for sensitivity analysis.

\begin{tabular}{|c|c|c|c|c|c|c|c|c|c|c|}
\hline $\begin{array}{l}\text { Farm } \\
\text { Type }\end{array}$ & & $\begin{array}{l}\text { Durum } \\
\text { Wheat }\end{array}$ & $\begin{array}{c}\text { OHM Durum } \\
\text { Wheat }\end{array}$ & $\begin{array}{l}\text { Faba } \\
\text { Beans }\end{array}$ & Chickpea & $\begin{array}{c}\text { Soft } \\
\text { Wheat }\end{array}$ & Alfalfa & Sunflower & Barley & Emmer \\
\hline Southern & Min & 337.92 & 337.92 & 295.68 & 580.80 & & & & 337.92 & \\
\hline Southern & Mode & 422.40 & 369.60 & 422.40 & 726.00 & & & & 726.00 & \\
\hline Southern & Max & 464.64 & 464.64 & 406.56 & 798.60 & & & & 464.64 & \\
\hline Central & Min & 360.00 & 360.00 & 28.00 & 370.00 & 360.00 & 70.00 & 400.00 & & 420.00 \\
\hline Central & Mode & 450.00 & 450.00 & 480.00 & 450.00 & 450.00 & 90.00 & 30.00 & & 90.00 \\
\hline Central & Max & 500.00 & 500.00 & 34.00 & 800.00 & 500.00 & 110.00 & 550.00 & & 560.00 \\
\hline
\end{tabular}


Table A2. Wheat case: Yields in ton/ha (Modi, minima, maxima) used for sensitivity analysis.

\begin{tabular}{|c|c|c|c|c|c|c|c|c|c|c|}
\hline $\begin{array}{l}\text { Farm } \\
\text { Type }\end{array}$ & $\begin{array}{l}\text { Yields } \\
\text { t/ha }\end{array}$ & $\begin{array}{l}\text { Durum } \\
\text { Wheat }\end{array}$ & $\begin{array}{l}\text { OHM Durum } \\
\text { Wheat }\end{array}$ & $\begin{array}{l}\text { Faba } \\
\text { Beans }\end{array}$ & Chickpea & $\begin{array}{c}\text { Soft } \\
\text { Wheat }\end{array}$ & Alfalfa & Sunflower & Barley & Emmer \\
\hline Southern & Min & 2.3 & 1.6 & 1.5 & 1 & & & & 2.1 & \\
\hline Southern & Mode & 2.8 & 2.3 & 1.8 & 1.4 & & & & 3.3 & \\
\hline Southern & Max & 4.5 & 2.7 & 2.6 & 2 & & & & 4.4 & \\
\hline Central & Min & 3 & 2 & 1.5 & 1.2 & 2 & 5 & 1.4 & & 2 \\
\hline Central & Mode & 3.5 & 2.7 & 2 & 1.5 & 2.5 & 7 & 1.8 & & 2.5 \\
\hline Central & Max & 4 & 3.4 & 2.5 & 1.8 & 3 & 8 & 2.2 & & 3 \\
\hline
\end{tabular}

Table A3. Perennial ryegrass case: Farm gate prices for lamb in $€$ /ha pasture (Modi, minima, maxima) used for sensitivity analysis.

\begin{tabular}{ccc}
\hline Farm Type & Low Land & Upland \\
\hline Min & 603.1 & 621.1 \\
\hline Mode & 768 & 786 \\
\hline Max & 896.89 & 914.89 \\
\hline
\end{tabular}

\section{Appendix B}

\section{Appendix B.1. Additional Information on the Typical Actors of Case 1, Durum Wheat}

Seed multiplication: Data was collected from one company representing this type. Reported differences in costs between NCT and organic seed are mainly at the seed production level, as organic seed production has $40 \%$ lower yields. However, with the possibility to charge a higher price for organic seed, the company finds it slightly more profitable to sell organic than NCT seed.

Breeding: The majority of the breeding companies focus their activities on the needs of conventional farmers, and the selection is conducted solely under non-organic conditions (i.e. no particular breeding program for organic) or the breeding program for organics is shared with conventional. Nevertheless, as some of these varieties may perform relatively well under organic conditions, the breeding companies are usually investing in post-release organic variety testing to understand which varieties may be selected for multiplication under organic conditions.

There is a yearly breeding budget of around $€ 200,000$ for durum wheat, both nonorganic and organic. Breeding activities are usually re-financed through royalties or levied on the seed price of a protected variety. The company produces around one new durum wheat cultivar yearly to stay competitive. It needs around 55,000 ha of durum wheat to re-finance its operations. The organic market it currently supplies makes up about $20 \%$ of this area. This shows that breeding activities solely for organic agriculture could not be sufficiently financed.

There are no organic breeding activities so far in Italy. However, some initiatives are likely to be started in the near future (e.g., a cooperation with the Swiss organic cereal breeding initiative Getreidezüchtung Peter Kunz and the CREA-CER: Centro di ricerca per la cerealicoltura). However, there are some attempts at breeding heterogeneous material, which is considered especially suited for organic agriculture.

\section{Appendix B.2. Additional Information on the Typical Actors of Case 2, Perennial Ryegrass}

Seed multiplication: Seed multiplication for perennial ryegrass occurs mainly in Northern and Central European countries, representing the most commonly used forage grass in many pasture seed mixtures. It is often sown in short-term leys (temporary grassland) together with clover and other forage species. 
The interviewees reported some technical/agronomic issues in the multiplication of perennial ryegrass under organic compared to non-organic conditions. One of the essential problems is the difficulty to provide adequate nutrient supply, especially nitrogen, resulting in lower seed yields. Thus, this aspect was taken up as a scenario in this study. [34]. Overall, seed companies reported between $20 \%$ and $40 \%$ lower yields for organic compared to nonorganic production, with reductions. The scientific literature on this is limited to research conducted in Denmark years ago, which reports a yield reduction in organic perennial ryegrass seed production of approximately $25 \%$ compared to conventional [34,35].

The chosen company type represents an important player in the UK organic forage seed market. Reported differences in costs between not chemically treated and organic seed are mainly at seed production level because of lower seed yields. Furthermore, higher labour costs for manual weeding in organic seed production is another critical factor. However, with the possibility of charging a higher price for organic seed mixtures, the company finds it more profitable to sell organic than NCT seed provided that they are able to match the demand in terms of seed amount and variety request.

Breeding: A few multinational seed companies fund their own (non-organic) breeding programs for forage through seed sales. This is the case of the non-organic breeding activities carried out for the most common species (particularly perennial ryegrass, white clover and red clover), which have the biggest market share within the forage sector. The only European breeding programs for organic farming in the forage sector we were able to identify are conducted by a public research institute in Switzerland. These organic breeding programs include both clover and grass species. The programs' goals focus on disease resistance, competitiveness against weeds, high yields under low nitrogen inputs. The financing model of this specific case is based on a partnership between the research institute and a small-medium seed company, where the research institute is responsible for the fundamental breeding work. The company then organises the registration, enlisting in the national variety list, and the basic seed production. Public funding and revenues from royalties constitute the basis of the breeding and registration of varieties. The seed of the most suitable varieties is multiplied under organic conditions and commercialised. As mentioned above, in the UK, most grass mixture seed is imported from larger seed production and breeding companies. Thus, such an actor was chosen in the simulation model. Breeding is part of the seed company. There is a yearly breeding budget of around 1 Mio $€$ for perennial ryegrass, both conventional and organic. There are no specific breeding activities for organic ryegrass production. The company produces three to five new perennial ryegrass cultivars yearly to stay competitive. It needs around 2.67 Mio ha of perennial ryegrass to re-finance its operations. The organic market it currently supplies makes up $17 \%$ of this area. This shows that breeding activities solely for organic agriculture could not be sufficiently financed.

Appendix C. 
Table A4. Simplified matrix overview of the MP decision-making model at farm level.

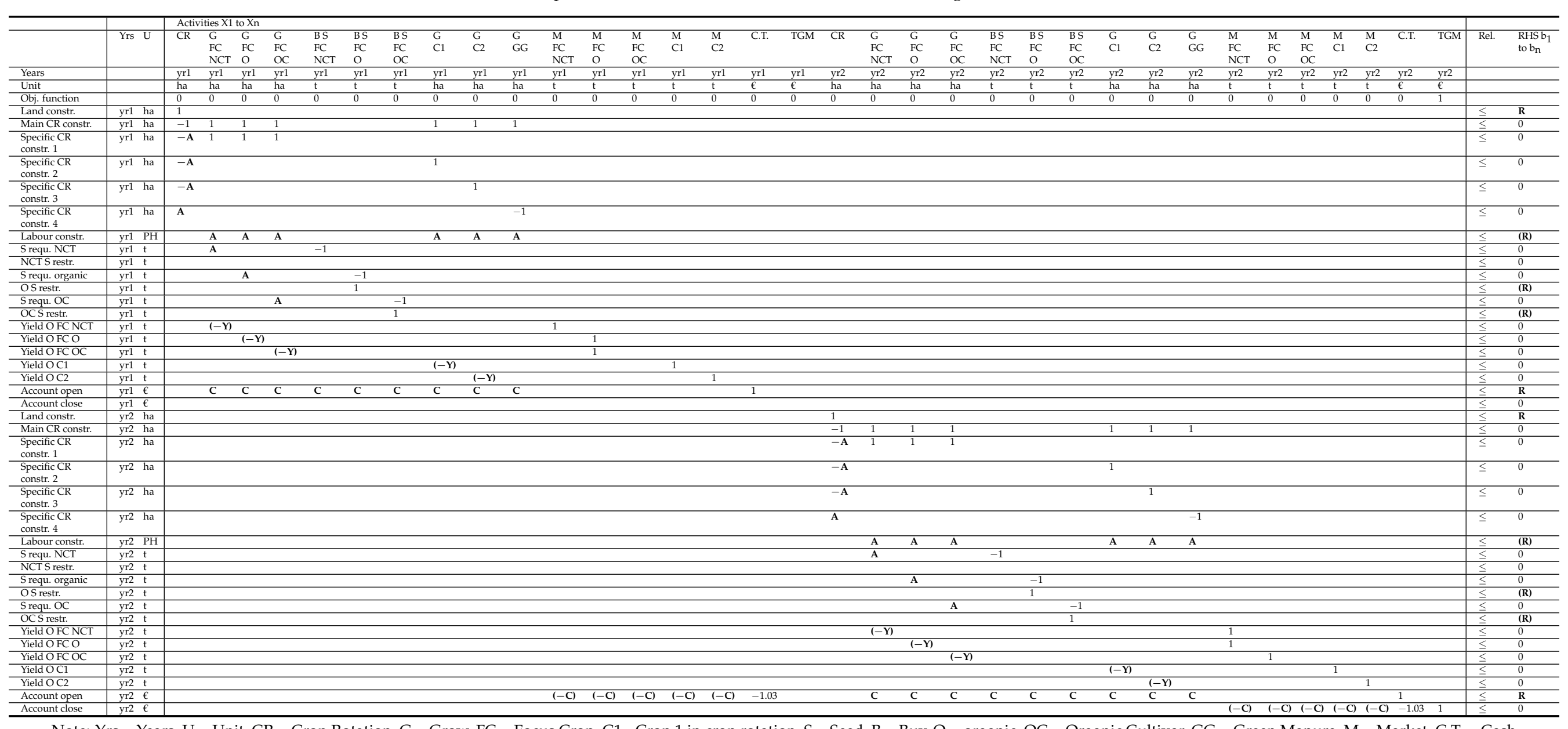

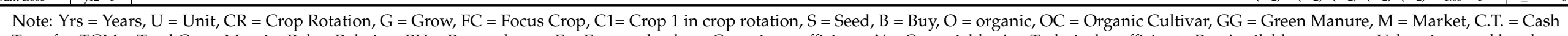

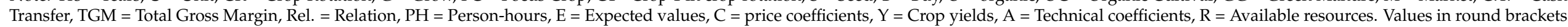
are adjusted inside the model. Bold values are agent-specific. 
Table A5. Simplified matrix overview of the MP decision-making model at seed multiplication level.

\begin{tabular}{|c|c|c|c|c|c|c|c|c|c|c|c|c|c|c|c|c|c|c|c|c|c|c|c|c|c|c|}
\hline & 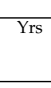 & $\begin{array}{l}\text { Unit } \\
\end{array}$ & $\begin{array}{l}\text { AAtiv } \\
\text { PSCT } \\
\text { NCT }\end{array}$ & $\begin{array}{l}\frac{1}{1} \text { to } \\
\text { PS } \\
\text { org. }\end{array}$ & $\begin{array}{l}P S \\
\text { org. } \\
\text { cult. }\end{array}$ & $\begin{array}{l}\text { BBS } \\
\text { NCT }\end{array}$ & $\begin{array}{l}\text { B BS } \\
\text { org. }\end{array}$ & $\begin{array}{l}\begin{array}{l}\mathrm{BBS} \\
\text { org. } \\
\text { cult. }\end{array} \\
\text { culs }\end{array}$ & $\begin{array}{l}\text { MS } \\
\text { NCT }\end{array}$ & $\begin{array}{l}\text { MS } \\
\text { org. }\end{array}$ & $\begin{array}{l}\text { MS } \\
\text { org. } \\
\text { cult. }\end{array}$ & $\begin{array}{l}\text { Cash } \\
\text { T. }\end{array}$ & $\begin{array}{l}\text { Tot. } \\
\text { GM }\end{array}$ & $\begin{array}{l}\text { PS } \\
\text { NCT }\end{array}$ & $\begin{array}{l}\text { PS } \\
\text { org. }\end{array}$ & $\begin{array}{l}\text { PS } \\
\text { org. } \\
\text { cult. }\end{array}$ & $\begin{array}{l}\text { BBS } \\
\text { NCT }\end{array}$ & $\begin{array}{l}\text { B BS } \\
\text { org. }\end{array}$ & $\begin{array}{l}\begin{array}{l}\mathrm{BBBS} \\
\text { org. } \\
\text { cult. }\end{array} \\
\text { culs }\end{array}$ & $\begin{array}{l}\text { MS } \\
\text { NCT }\end{array}$ & $\begin{array}{l}\text { MS } \\
\text { org. }\end{array}$ & $\begin{array}{l}\text { MS } \\
\text { org. } \\
\text { cult. }\end{array}$ & $\begin{array}{l}\text { Cash } \\
\text { T. }\end{array}$ & $\begin{array}{l}\text { Tot. } \\
\text { GM }\end{array}$ & Relation & RHS $b_{1}$ to $b_{n}$ \\
\hline $\begin{array}{l}\text { Years } \\
\text { Unit } \\
\end{array}$ & & & $\begin{array}{ll}\mathrm{yr} 1 \\
\mathrm{t}\end{array}$ & $\begin{array}{lll}\mathrm{yr} 1 \\
\mathrm{t}\end{array}$ & $\begin{array}{lll}y r 1 \\
t\end{array}$ & $\frac{\mathrm{yr} 1}{\mathrm{t}}$ & $\begin{array}{ll}y r 1 \\
t\end{array}$ & $\frac{\mathrm{yr} 1}{\mathrm{t}}$ & $\begin{array}{ll}y r 1 \\
t\end{array}$ & $\begin{array}{lll}\mathrm{yr} 1 \\
\mathrm{t}\end{array}$ & $\frac{\mathrm{yr} 1}{\mathrm{t}}$ & $\frac{y r 1}{\epsilon}$ & $\frac{y r 1}{\epsilon}$ & $\begin{array}{l}y+2 \\
t\end{array}$ & $\frac{y+2}{t}$ & $\frac{\mathrm{yr} 2}{\mathrm{t}}$ & $\frac{\mathrm{yr2}}{\mathrm{t}}$ & $\frac{\mathrm{yr2}}{\mathrm{t}}$ & $\frac{\mathrm{yr} 2}{\mathrm{t}}$ & $\frac{\mathrm{yr} 2}{\mathrm{t}}$ & $\frac{y+2}{t}$ & $\frac{\mathrm{yr} 2}{\mathrm{t}}$ & $\frac{\mathrm{yr} 2}{\epsilon}$ & $\frac{\mathrm{yr} 2}{\epsilon}$ & & \\
\hline Obj. function & & & 0 & 0 & 0 & 0 & 0 & 0 & $\frac{2}{0}$ & 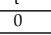 & 0 & 0 & 0 & $\frac{t}{0}$ & $\frac{t}{0}$ & $\frac{1}{0}$ & 0 & $0_{0}$ & 0 & 0 & 0 & 0 & 0 & 1 & & \\
\hline $\begin{array}{l}\text { Typical organic market } \\
\text { size constr. }\end{array}$ & $\mathrm{yr} 1$ & ha & A & A & & & & & & & & & & & & & & & & & & & & & $\leq$ & Typical organic market size \\
\hline $\begin{array}{l}\text { Typicalal organicic cultivar } \\
\text { market size constr. }\end{array}$ & $\mathrm{yr} 1$ & ha & & & A & & & & & & & & & & & & & & & & & & & & $\leq$ & $\begin{array}{l}\text { Typical organic cultivar } \\
\text { market size }\end{array}$ \\
\hline $\begin{array}{l}\text { Basic seed requ. NCT } \\
\end{array}$ & $\mathrm{yr} 1$ & $t$ & A & & & -1 & & & & & & & & & & & & & & & & & & & $\leq$ & \\
\hline $\begin{array}{l}\text { Basic seed requ. organic } \\
\end{array}$ & $\mathrm{yr} 1$ & $t$ & & $\mathbf{A}$ & & & -1 & & & & & & & & & & & & & & & & & & $\leq$ & 0 \\
\hline $\begin{array}{l}\text { Basic seed requ. organic } \\
\text { cultivar }\end{array}$ & $\mathrm{yr} 1$ & $\mathrm{t}$ & & & A & & & -1 & & & & & & & & & & & & & & & & & $\leq$ & 0 \\
\hline Basic organic seed constr. & $\mathrm{yr} 1$ & $t$ & & & & & 1 & & & & & & & & & & & & & & & & & & $\leq$ & (R) \\
\hline 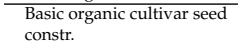 & yr1 & $\mathrm{t}$ & & & & & & 1 & & & & & & & & & & & & & & & & & $\leq$ & (R) \\
\hline $\begin{array}{l}\text { Seed yield NCT } \\
\text { Seed yield organic }\end{array}$ & $\mathrm{yr} 1$ & $t$ & & & & & & & 1 & & & & & & & & & & & & & & & & $\leq$ & (E $\mathrm{E}_{\mathrm{NCT}}$ seed sales) \\
\hline $\begin{array}{l}\text { Seed yield organic } \\
\text { Seed yield organic cultivar }\end{array}$ & $\begin{array}{c}\mathrm{yr} 1 \\
\mathrm{vr} 1\end{array}$ & $t^{t}$ & & & & & & & & 1 & & & & & & & & & & & & & & & $\leq$ & $\left(E_{\text {organic seed sales }}\right)$ \\
\hline Seed yield organic cultivar & $\mathrm{yr} 1$ & $\mathrm{t}$ & & & & & & & & & 1 & & & & & & & & & & & & & & $\leq$ & (Eorganic cultivar seed sales) \\
\hline $\begin{array}{l}\begin{array}{l}\text { Expected organic seed } \\
\text { sales }\end{array} \\
\end{array}$ & yr1 & $t$ & & & & & & & & & & & & & & & & & & & & & & & $\leq$ & \\
\hline $\begin{array}{l}\text { Expected organic cultivar } \\
\text { sales }\end{array}$ & $\mathrm{yr} 1$ & $\mathrm{t}$ & & & & & & & & & & & & & & & & & & & & & & & $\leq$ & 0 \\
\hline Account open & $\mathrm{yr} 1$ & $\epsilon$ & $\mathrm{C}$ & C & $\mathrm{C}$ & C & C & C & $\mathrm{C}$ & C & C & 1 & & & & & & & & & & & & & $\leq$ & $\mathbf{R}$ \\
\hline Account close & $\mathrm{yr} 1$ & $\epsilon$ & & & & & & & & & & & & & & & & & & & & & & & $\leq$ & \\
\hline $\begin{array}{l}\text { Typical organic market } \\
\text { size constr. }\end{array}$ & $\mathrm{yr} 2$ & ha & & & & & & & & & & & & $\mathbf{A}$ & $\mathbf{A}$ & & & & & & & & & & $\leq$ & Typical organic market size \\
\hline $\begin{array}{l}\text { Typical organic cultivar } \\
\text { market size constr. }\end{array}$ & $\mathrm{yr} 2$ & ha & & & & & & & & & & & & & & A & & & & & & & & & $\leq$ & $\begin{array}{l}\text { Typical organic cultivar } \\
\text { market size }\end{array}$ \\
\hline $\begin{array}{l}\text { Basic seed requ. NCT } \\
\end{array}$ & $\mathrm{yr} 2$ & $\mathrm{t}$ & & & & & & & & & & & & $\mathbf{A}$ & & & -1 & & & & & & & & $\leq$ & 0 \\
\hline $\begin{array}{l}\text { Basic seed requ. organic } \\
\end{array}$ & $\mathrm{yr} 2$ & $t$ & & & & & & & & & & & & & $\mathbf{A}$ & & & -1 & 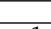 & & & & & & $\leq$ & 0 \\
\hline $\begin{array}{l}\text { Basic organic cultivar seed } \\
\text { constr. }\end{array}$ & $\mathrm{yr} 2$ & $\mathrm{t}^{\mathrm{s}}$ & & & & & & & & & & & & & & & & & 1 & & & & & & $\leq$ & (R) \\
\hline Seed yield NCT & $\mathrm{yr} 2$ & $\mathrm{t}$ & $-\mathrm{Y}$ & & & & & & & & & & & & & & & & & 1 & & & & & $\leq$ & 0 \\
\hline $\begin{array}{l}\text { Seed yield organic } \\
\text { Seed vield organic cultivar }\end{array}$ & $\frac{\mathrm{yr} 2}{\mathrm{yr} 2}$ & $\frac{t}{t}$ & & $-\mathrm{YY}$ & $-Y$ & & & & & & & & & & & & & & & & 1 & 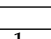 & & & $\leq$ & 0 \\
\hline $\begin{array}{l}\text { Seed yield organic cultivar } \\
\text { Expected organic seed } \\
\text { sales }\end{array}$ & $\begin{array}{l}\mathrm{yr} 2 \\
\mathrm{yr} 2\end{array}$ & $\frac{t}{t}$ & & & $-Y$ & & & & & & & & & & & & & & & & 1 & 1 & & & $\begin{array}{l}\leq \\
\leq \\
\leq\end{array}$ & $\begin{array}{l}0 \\
\left(E_{\text {organic seed sales }}\right)\end{array}$ \\
\hline $\begin{array}{l}\text { Expected organic cultivar } \\
\text { sales }\end{array}$ & $\mathrm{yr} 2$ & $t^{t}$ & & & & & & & & & & & & & & & & & & & & 1 & & & $\leq$ & (E \\
\hline $\begin{array}{l}\text { Account open } \\
\text { ccost the }\end{array}$ & $\mathrm{yr} 2$ & $\bar{\epsilon}$ & $\mathrm{C}$ & $\mathrm{C}$ & $\mathrm{C}$ & & & & $-\mathrm{C}$ & $-\mathrm{C}$ & $-\mathrm{C}$ & -1.03 & & $\mathrm{C}$ & $\mathrm{C}$ & $\begin{array}{cc}\mathrm{C} \\
\mathrm{C}\end{array}$ & $\mathrm{C}$ & $\mathrm{C}$ & $\mathrm{C}$ & $\frac{-\mathrm{C}}{-\mathrm{C}}$ & $\frac{-\mathrm{C}}{-\mathrm{C}}$ & & & & $\leq$ & 0 \\
\hline Account close & $\mathrm{yr} 2$ & $\epsilon$ & & & & & & & & & & & & $\mathrm{C}$ & $\mathrm{C}$ & $\mathrm{C}$ & & & & $-\mathrm{C}$ & $-\mathrm{C}$ & & -1.03 & 1 & $\leq$ & 0 \\
\hline
\end{tabular}

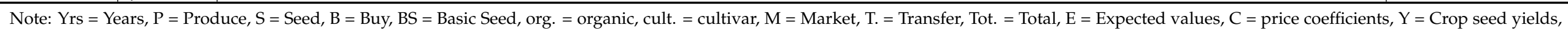

$\mathrm{A}=$ Technical coefficients, $\mathrm{R}=$ Available resources. Values in round brackets are adjusted inside the model. Bold values are agent-specific. 
Table A6. Simplified matrix overview of the MP decision-making model at breeding level.

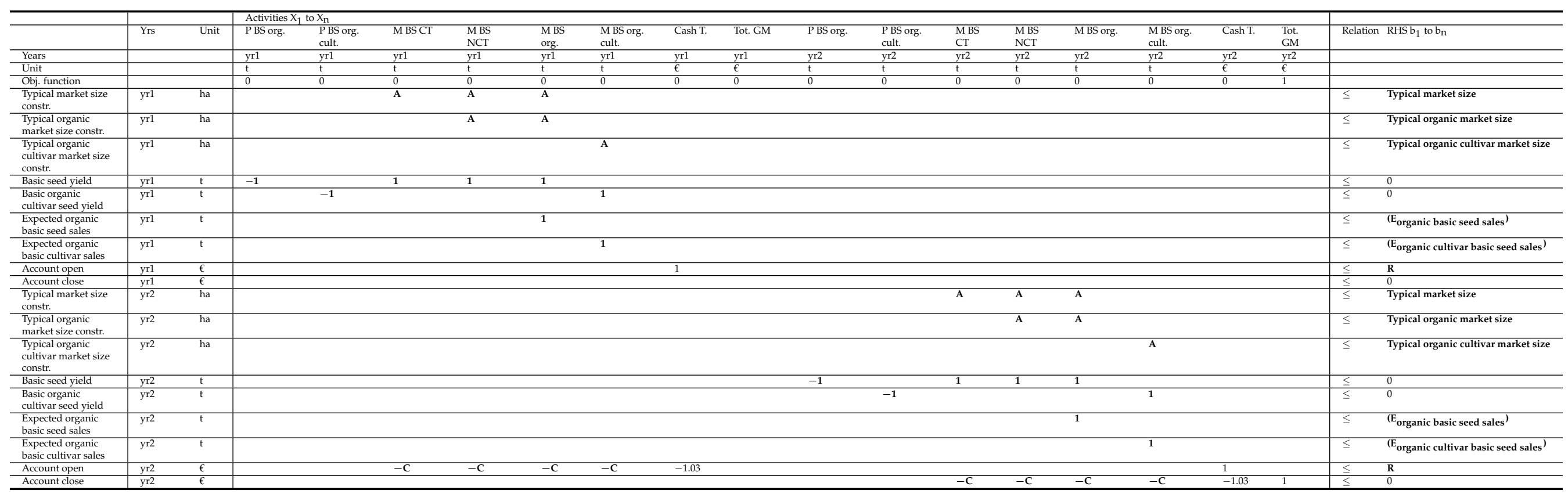

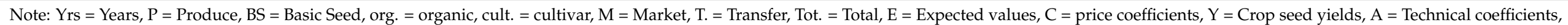

$\mathrm{R}=$ Available resources. Values in round brackets are adjusted inside the model. Bold values are agent-specific. 


\section{References}

1. European Commission. Farm to Fork Strategy for a Fair, Healthy and Environmentally-Friendly Food System. 2020. Available online: https:/ / ec.europa.eu/food/sites/food/files/safety/docs/f2f_action-plan_2020_strategy-info_en.pdf (accessed on 10 September 2020).

2. Solfanelli, F.; Schäfer, F.; Ozturk, E.; Zanoli, R.; Orsini, S. The State of Organic Seed in Europe. 2019. Available online: https: //www.liveseed.eu/wp-content/uploads/2019/12/FNL-FNL-Web-Interactive-NOV19-Booklet2-LIVESEED_web.pdf (accessed on 15 December 2020).

3. New Organic Regulation 848/2018. Regulation (EU) 2018/848 of the European Parliament and of the Council of 30 May 2018 on Organic Production and Labelling of Organic Products and Repealing Council Regulation (EC) No 834/2007. Available online: https:/ / eur-lex.europa.eu/legal-content/EN/TXT/?uri=CELEX\%3A32018R0848 (accessed on 15 December 2020).

4. Döring, T.F.; Bocci, R.; Hitchings, R.; Howlett, S.; van Bueren, E.T.L.; Pautasso, M.; Raaijmakers, M.; Rey, F.; Stubsgaard, A.; Weinhappel, M.; et al. The Organic Seed Regulations Framework in Europe. Organic Agriculture. Org. Agric. 2012, 2, 173-183. [CrossRef]

5. Padel, S.; Orsini, S.; Solfanelli, F.; Zanoli, R. Can the Market Deliver 100\% Organic Seed and Varieties in Europe? Sustainability 2021, 13, 10305. [CrossRef]

6. Winter, E.; Grovermann, C.; Messmer, M.M.; Aurbacher, J. Analysing interventions in the seed and breeding system for organic carrot seed use in Germany-A multi-agent value chain approach. In Proceedings of the 31st Edition of the International Conference of Agricultural Economists, Online Conference, 17-31 August 2021.

7. Orsini, S.; Solfanelli, F.; Winter, E.; Padel, S.; Ozturk, E. Report Describing Three Crop Case Studies Investigating in Detail the Socio-Economic Factors Influencing the Behaviour of Various Stakeholders Regarding the use of Organic Seed. 2019. Available online: https:/ /www.liveseed.eu/wp-content/uploads/2020/02/LIVESEED-D4.2-Report-describing-three-crop-casestudies-investigating-in-detail-the-socio-economic-factors-influencing-the-behaviour-of-various-stakeholders-regarding-theuse-of-organic-seed.0203.pdf (accessed on 10 December 2020).

8. Fuss, A.; Kovács, T.; Raaijmakers, M.; Schäfer, F.; Gatzert, X.; Brühl, K.; Petitti, M.; Bocci, R. How to Implement the Organic Regulation to Increase Production \& Use of Organic Seed. 2020. Available online: https://www.liveseed.eu/wp-content/ uploads/2020/05/FNL-WEB-LIVESEED-All-Pages-Booklet1Changes_compressed.pdf (accessed on 15 December 2020).

9. Bickler, C. Organic Heterogeneous Material-Opportunities and Challenges. 2018. Available online: https://orgprints.org/id/ eprint/34953/ (accessed on 15 December 2020).

10. Messmer, M.; Bocci, R.; Bianchi, P.G.; Bickler, C.; Kovács, T.; Pederson, T.M.; Rossmanith, G. Presentations at the LIVESEED-ECOPB \& CPVO Workshop on Organic Heterogeneous Material and Organic Varieties. 2018. Available online: https://orgprints.org/ id/eprint/38044/ (accessed on 10 December 2020).

11. Janssen, S.; van Ittersum, M.K. Assessing farm innovations and responses to policies: A review of bio-economic farm models. Agric. Syst. 2007, 94, 622-636. [CrossRef]

12. Rich, K.M.; Ross, R.B.; Baker, D.; Negassa, A. Quantifying value chain analysis in the context of livestock systems in developing countries. Food Policy 2011, 36, 214-222. [CrossRef]

13. Nang'ole, E.; Mithöfer, D.; Franzel, S. Review of Guidelines and Manuals for VCA for Agricultural and Forest Products. 2011. Available online: https://dlc.dlib.indiana.edu/dlc/bitstream/handle/10535/7718/OP11160.pdf (accessed on 15 December 2020).

14. Hazell, P.B.R.; Norton, R.D. Mathematical Programming for Economic Analysis in Agriculture. Biometrics 1987, 43, 1032. [CrossRef]

15. Troost, C.; Berger, T. Dealing with Uncertainty in Agent-Based Simulation: Farm-Level Modeling of Adaptation to Climate Change in Southwest Germany. Am. J. Agric. Econ. 2015, 97, 833-854. [CrossRef]

16. Grovermann, C.; Schreinemachers, P.; Riwthong, S.; Berger, T. 'Smart' policies to reduce pesticide use and avoid income trade-offs: An agent-based model applied to Thai agriculture. Ecol. Econ. 2017, 132, 91-103. [CrossRef]

17. Kuin, B. Breeding for Organic or Organic Breeding. In Biofach; Bejo Zaden: Nuremberg, Germany, 2018.

18. Syngenta. Financial Business Case for Breeding Programs. In Educational Material; Syngenta Foundation for Sustainable Agriculture: Enkhuizen, The Netherlands, 2015.

19. Galbács, P. The Theory of New Classical Macroeconomics; Contributions to Economics; Springer: Cham, Switzerland, 2015. [CrossRef]

20. Thünen Institute. A Standard Operating Procedure to Define Typical Organic Farms. 2016. Available online: www.agribenchmark. org/fileadmin/Dateiablage/B-Organic/SOPOrganic-170426.pdf (accessed on 10 December 2020).

21. Chibanda, C.; Agethen, K.; Deblitz, C.; Zimmer, Y.; Almadani, M.; Garming, H.; Rohlmann, C.; Schütte, J.; Thobe, P.; Verhaagh, M.; et al. The Typical Farm Approach and Its Application by the Agri Benchmark Network. Agriculture 2020, 10, 646. [CrossRef]

22. Feuz, D.M.; Skold, M.D. Typical Farm Theory in Agricultural Research. J. Sustain. Agric. 1992, 2, 43-58. [CrossRef]

23. SINAB. Bio in Cifre 2020 (Sistema d'informazione Nazionale sull'Agricoltura Biologica). 2019. Available online: http:/ / www. sinab.it/sites/default/ files/2021-03/Bio\%20in\%20cifre\%202020.pdf (accessed on 15 December 2020).

24. Solfanelli, F.; Ozturk, E.; Orsini, S.; Schäfer, F.; Messmer, M.; Zanoli, R. The EU Organic Seed Sector-Statistics on Organic Seed Supply and Demand. 2020. Available online: https://orgprints.org/id/eprint/38616/ (accessed on 15 December 2020). 
25. Raaijmakers, M.; Heining, N.; Solfanelli, F.; Ozturk, E.; Zanoli, R.; Feher, J.; Schäfer, F. Creating Incentives for Farmers to use Organic Seed. 2020. Available online: https:/ /www.liveseed.eu/wp-content/uploads/2020/11/FNL-BOOKLET-6-WEB-.pdf (accessed on 10 December 2020).

26. Defra. Organic Farming Statistics. 2018. Available online: https://www.gov.uk/government/statistics/organic-farmingstatistics-2018 (accessed on 15 December 2020).

27. Regione Basilicata. PSR Basilicata: Bando di Attuazione Misura 11. 2021. Available online: https://bandi.regione.basilicata.it (accessed on 15 September 2021).

28. Regione Marche. PSR Marche: Bando di Attuazione Misura 11. 2021. Available online: https://bandi.regione.marche.it/Allegati/ 4510/DDS_SPA_2021_0276_A.pdf (accessed on 15 September 2021).

29. Bejo. 100\% Organic Seed EU 2035? 2021. Available online: https://www.bejo.com/magazine/100-organic-seed-eu-2035 (accessed on 15 September 2021).

30. European Commission. Key Policies: Producer and Interbranch Organisations. 2021. Available online: https://ec.europa.eu/ info/food-farming-fisheries/key-policies/common-agricultural-policy/market-measures/agri-food-supply-chain/producerand-interbranch-organisations_en (accessed on 15 September 2021).

31. Martin, G.; Durand, J.-L.; Duru, M.; Gastal, F.; Julier, B.; Litrico, I.; Louarn, G.; Médiène, S.; Moreau, D.; Valentin-Morison, M.; et al. Role of ley pastures in tomorrow's cropping systems. A review. Agron. Sustain. Dev. 2020, 40, 17. [CrossRef]

32. Wilhem, W. Perspective of a Public-Private Partnership: An Example of Collaboration of a Public Research Institute with a Small and Medium Enterprise in Switzerland. 2016. Available online: www.upov.int/edocs/mdocs/upov/en/upov_trainer_en_17 / upov_trainer_en_17_15.pdf (accessed on 10 December 2020).

33. Winter, E.; Grovermann, C.; Aurbacher, J.; Orsini, S.; Schäfer, F.; Lazzaro, M.; Solfanelli, F.; Messmer, M.M. Sow what you sell: Strategies for integrating organic breeding and seed production into value chain partnerships. Agroecol. Sustain. Food Syst. 2021, 45, 1500-1527. [CrossRef]

34. Loch, D.S. Proceedings: Fifth International Herbage Seed Conference: Herbage Seed in the New Millennium-New Markets, New Products, New Opportunities. In Proceedings of the Fifth International Herbage Seed Conference, Gatton, QLD, Australia, 23-26 November 2003.

35. Gislum, R.; Boelt, B. Intercropped Green Manure Legumes in Perennial Ryegrass (Lolium Perenne L.) for Organic Grass Seed Production. In Congress Handbook of 15th IFOAM Organic World Congress; IFOAM Abstracts: Adelaide, SA, Australia, 2005; Available online: https:/ / orgprints.org/id/eprint/7964/ (accessed on 10 December 2020). 